\title{
New insights on the relative sea level changes during the Late Holocene along the coast of Paros Island and the northern Cyclades (Greece)
}

\author{
Eleni Kolaiti*,1, Nikos Mourtzas ${ }^{2}$ \\ (1) National Hellenic Research Foundation, AKTES NPO, Kefallinias 16-18, 15231 Chalandri - Athens, Greece, \\ kolaitieleni@gmail.com,info@aktes.gr \\ (2) AKTES NPO, Kefallinias 16-18, 15231 Chalandri - Athens, Greece Athens, Greece, nikosmourtzas@gmail.com
}

Article history: received May 29, 2020; accepted September 30, 2020

\begin{abstract}
Geomorphological and archaeological indicators of former sea levels along the coast of Paros enabled us to determine and date six distinct sea level stands and the relative sea level (rsl) changes between them, as well as plot the rsl curve for the last 6,300 years.

The Late Holocene history of the rsl change in Paros began with the sea level at $4.90 \pm 0.10 \mathrm{~m}$ below mean sea level (bmsl) dated to the Late Neolithic period (4300 BC-3700 BC). The next sea level at 3.50 $\pm 0.20 \mathrm{~m}$ bmsl is dated to the Geometric and Archaic period of the Cyclades (1050 BC-490 BC) and most probably lasted during the Hellenistic period (323-146 BC). The sea level at $2.40 \pm 0.25 \mathrm{~m}$ bmsl is dated to the Roman period (146-400 AD) and the next sea level at $1.35 \pm 0.20 \mathrm{~m}$ bmsl to the Venetian period of the Cyclades (1207-1537). The sea level at $0.80 \pm 0.10 \mathrm{~m} \mathrm{bmsl}$ is dated to after the Venetian period, during the Ottoman rule of the island (1537-1821). The youngest sea level stand at $0.45 \pm 0.10$ $\mathrm{m}$ is attributed to the recent change in the sea level after the late $19^{\text {th }} \mathrm{c}$. onward. The separation between glacio-hydro-isostatic signals and the observed rsl change on Paros Island, in an area of seismic quiescence, demonstrates a significant tectonic component in the rsl changes. Moreover, the sea level stands deduced from Paros in comparison with those from the northern Cyclades indicate a uniform tectonic behaviour of the entire northern and central section of the Cyclades plateau.
\end{abstract}

Keywords: Paros Island; Cyclades; Greece; Relative sea level change; Archaeological sea level indicators; Geomorphological sea level indicators; Palaeogeographic reconstruction.

\section{Introduction}

Relative sea level (rsl) changes in the Mediterranean Sea are complex and variable, due to crustal dynamics, volcanism and glacio-isostatic adjustment [e.g. Benjamin et al., 2017]. The deglaciation of the two great northern hemisphere ice sheets over northern Europe and North America resulted in the sea level rising from the onset of deglaciation up until the present, as mantle materials continue to flow towards the region beneath the decaying ice sheets. At the same time, the water load in the Mediterranean basin has increased, depressing the sea floor and adjacent margins regionally according to its distribution. These two contributions result in a regional variation in 


\section{Eleni Kolaiti and Nikos Mourtzas}

the Last Glacial Maximum (LGM) sea levels ( 20,000 years ago) from $100 \mathrm{~m}$ to $135 \mathrm{~m}$ below present, with associated strong gradients in the load stresses in the lithosphere and crust across the continental margins [Lambeck, 2014]. This glacio-hydro-isostatic adjustment model is combined with the active tectonics of the Mediterranean region driven by the long-lasting convergence of the African and Eurasian tectonic plates running along an east-west boundary [Anzidei et al., 2014].

The enhanced rates of the sea level rise after the "Younger Dryas" cold event, between 11000 and 8800 BP, including a probable peak rate of rise of 13-15 mm/yr at around 9500 BP [Stanford et al., 2011], abruptly decreased to $1-1.50 \mathrm{~mm} / \mathrm{yr}$ after $6800 \mathrm{BP}$ [Lambeck et al., 2011]. Data collected from tectonically stable regions for the last 4000 years indicate that the sea level was close to present levels [e.g. Galili et al., 2005; Galili and Sharvit, 1998; Porat et al., 2008]. Furthermore, the Industrial Revolution and the accelerated climate change from the eighteenth century onward have brought about a global rise in sea level of $0.25 \pm 0.05 \mathrm{~m}$ [Church et al., 2011; Cazenave et al., 2014; Jevrejeva et al., 2014].

Rsl change curves for the last 6,000 years have been constructed in Italy, Croatia and Slovenia, southern France and Corsica, Turkey, Greece, Tunisia and Libya, Israel and Lebanon [e.g. Benjamin et al., 2017 and related references therein], integrating data from precise - in terms of the timing and rate of the rsl change - geomorphological and archaeological indicators.

A series of publications on the rsl changes of the central Aegean [Mendoni and Mourtzas, 1990; Mourtzas and Kolaiti, 1998; Mourtzas, 2007; Baika, 2008; Poulos et al., 2008; Desruelles et al., 2009; Kapsimalis et al., 2009; Pavlopoulos et al., 2011; Mourtzas, 2010, 2012, 2018; Evelpidou et al., 2012a, b, 2014, 2018; Mourtzas and Kolaiti 2016; Karkani et al., 2017, 2018, 2019], suggesting a gradual subsidence of the Cyclades plateau during the Late Holocene period, nevertheless present different results in terms of the former sea level stands and estimated rates of rsl change.

In this study, reliable geomorphological and archaeological rsl indicators from the Late Neolithic to Modern Times found on Paros Island were used, with the aim of collecting new data on the rsl changes that have occurred along the coast of Paros during the last 6,300 years. The geoarchaeological interpretation of ancient maritime and coastal installations plays a decisive role in the estimation of the intervening rsl changes along the coast of Paros. The determination of the former sea level stands enables the estimation of the trend and rates of vertical tectonic movements for both Paros Island and the northern Cyclades area. The results of this study, coupled with geomorphological markers and archaeological interpretations of ancient submerged remains throughout the northern Cyclades, and compared with the suggested sea level predictive models for the central Aegean [Lambeck, 1996; Lambeck and Purcell, 2005; Peltier et al., 2015; Roy and Peltier, 2018; Stocchi et al., 2010], contribute to the validation of both sea level predictions and the estimation of the rsl rise during the Late Holocene period, as well as the tectonic component included in it.

\section{Regional setting}

Paros is located in the central part of the Cyclades between Naxos and Antiparos and is the fourth largest island in the central Aegean (Figures 1a, b). It is almost ellipsoidal in shape, decreasing towards the North and its major axis oriented NE-SW. It occupies an area of $193.31 \mathrm{~km}^{2}$ and its coastline has a length of $118.5 \mathrm{~km}$. The low coastal relief gradually turns to mountainous inland terrain, with the central mass reaching $771 \mathrm{~m}$. The rugged coastal landscape with small bays and capes is dominated by the gulfs of Naoussa on the north and Paroikia on the west side of the island, whereas cliffs prevail on the NW shores (Figure 1c).

Paros Island forms a NE-SW trending dome bounded by a low-angle inactive normal fault to the east and northeast [Bargnesi et al., 2013] within the Cycladic metamorphic complex, composed of four lithostratigraphic units [Papanikolaou, 1977, 1980; Robert, 1982; Gautier et al., 1993; Brichau et al., 2006; Bargnesi et al., 2013; Malandri et al., 2016] (Figure 1d). The Marmara Unit is the upper tectonostratigraphic unit consisting of serpentinised peridotites, clastic sedimentary formations, Cretaceous limestones and Miocene conglomerates, sandstones, and sandy marls, intensely deformed with faults and folds, juxtaposed against the underlying Marathi and pre-Alpine basement units by a detachment, showing in general a top-to-the-N sense of shear [Malandri et al., 2016]. The Molasse of Paros of Burdigalian age is the upper formation of the Marmara nappe, dominated by sandstones and conglomerates, rare marls and unconformable travertines on top [Dermitzakis and Papanikolaou, 
1980]. The Drios Unit overlies the Marathi Unit and consists of metabasites, meta-calcareous rocks, phyllites, and schists, highly schistosed and folded, having undergone low-to-medium grade metamorphism, up to greenschist facies [Robert, 1982; Malandri et al., 2016]. The Marathi Unit is considered to be the Cycladic Blueschist Unit and consists of intensely folded amphibolites, amphibolitic schists intercalated with thin layers of impure marbles, metabauxite-bearing marbles, quartzofeldspathic rocks and mica schists. [Robert, 1982; Gautier et al., 1993; Bargnesi et al., 2013]. The pre-Alpine basement consisting of deformed orthogneisses is characterised by a gneissic foliation [Malandri et al., 2016]. Numerous granitic intrusions, associated with the migmatitic dome and aplitic and pegmatitic dikes, are observed in the northern part of the island [Malandri et al., 2016]. Pliocene travertine limestones and breccias, usually silicified, correspond to a marine terrace with gradual transition to terrestrial. Quaternary deposits mainly develop in the lower topographic areas on the NE and SE sides of the island.

Located between the two recently thinned regions of the North Aegean and the Cretan Sea, the Cyclades domain - in the centre of which lies Paros Island - with an average crustal thickness of $25 \mathrm{~km}$ moved as a rigid block towards the South and does not seem to have accommodated any additional extension since the Late Miocene period. Strain rates and GPS velocities in the Cyclades show a relative motion towards SW at a rate of 33-34 mm/yr during the Holocene period [Le Pichon et al., 1995; Kahle et al., 1998; Kreemer and Chamot-Rooke, 2004] and scarce and scattered seismicity [Engdahl et al., 1998].

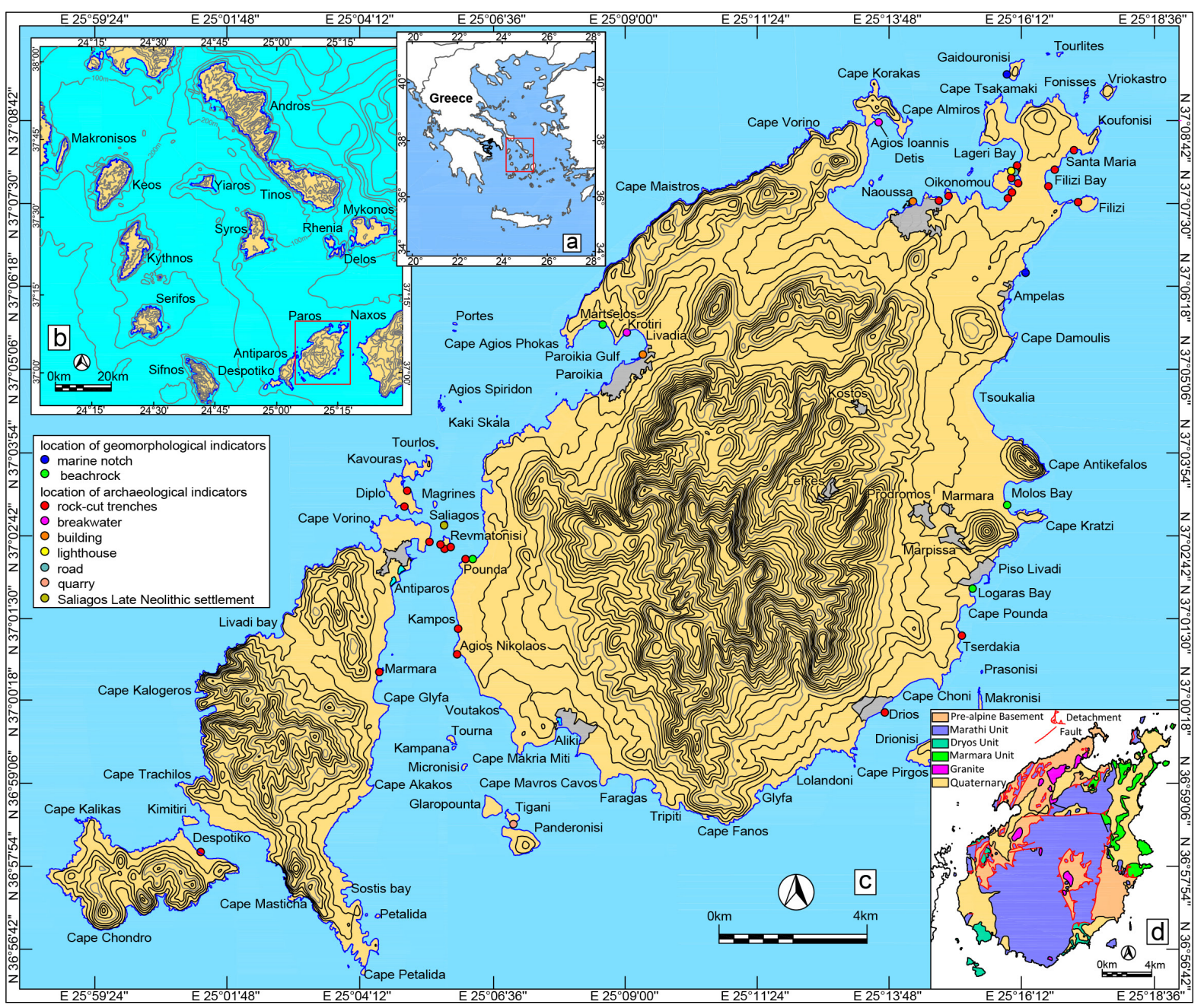

Figure 1. Location maps of: (a) the Cyclades; (b) Paros Island in the Cycladic archipelago; (c) the geomorphological and archaeological indicators along the coast of Paros; (d) simplified geological map of Paros Island (modified after Malandri et al., [2016]). 


\section{Eleni Kolaiti and Nikos Mourtzas}

A large portion of the seismic activity within the upper crust is associated with the presence of islands representing horst structures that were generated during the major Oligocene extensional phase. In contrast, the central part of the Cycladic metamorphic core, which today represents the major part of the Cyclades insular group, remains aseismic [Bohnhoff et al., 2006]. Lykousis [2009] noted continuous and gradual subsidence of the Aegean margins during the last $400 \mathrm{kyr}$. The lowest subsidence values $(0.34-0.60 \mathrm{~mm} / \mathrm{yr})$ are related to the low tectonic and seismic activity of the Cyclades plateau, with a gradual decrease in the intensity of the extensional tectonic regime and a decreased isostatic rebound after the Early Pleistocene compressional phase in the Aegean domain [Lykousis, 2009]. The highest seismic activity was identified along the SW-NE striking Santorini-Amorgos zone. The two largest earthquakes in the entire Aegean Sea in the $20^{\text {th }}$ century occurred in 1956, both striking within a period of only 13 minutes, and with magnitudes of Ms=7.8 and 7.2, respectively, on the Richter scale [Papadopoulos and Pavlides, 1992; Papazachos et al., 2000; Okal et al., 2009].

\section{Methodology approach}

The determination of the several sea level stands along the coast of Paros was based on geomorphological indicators, i.e. marine tidal notches and various beachrock generations. Marine notches are deep undercuts in rocky, mainly carbonate, cliffs. They are formed in the intertidal zone during a period of rsl stability through a complex biological, physicochemical and mechanical erosional process [e.g. Carobene, 1972, 2015; Higgins, 1980; Pirazzoli, 1986; Kelletat, 1997, 2005; Antonioli et al., 2015; Trenhaile, 2015; Kolaiti, 2019]. In microtidal protected coastal environments such as that of the Aegean (mean tidal range $0.13 \mathrm{~m}$, tide-gauge station of Syros port), marine notches show an asymmetrical profile with an elongated and almost horizontal base, maximum inward depth close to the base, and roof usually dipping inwards, depending on their exposure. The mean sea level is slightly below or at the same elevation as the notch base, which statistically during much of the tidal pattern is submerged and only slightly protrudes from the mean low water [Kolaiti, 2019]. The inward depth depends on the duration of the rsl stability period and its maximum is at the mean high water [e.g. Antonioli et al., 2015; Kolaiti, 2019].

Beachrocks are formed by the cementation of coastal sediments, including anthropogenic deposits, during periods of rsl stability [e.g. Hopley, 1986; Strasser et al., 1989; Bernier et al., 1997; Plomaritis, 1999; Turner, 2005; Vousdoukas et al., 2007; Erginal and Öztürk, 2012; Mauz et al., 2015; Avcioğlu et al., 2016]. Cementation takes place in the coastal zone that is bounded on the seaward end by the mean low water and on the landward end by the uppermost limit of the swash and backwash zone [e.g. Bernier and Dalongenville, 1996; Vousdoukas et al., 2007; Desruelles et al., 2009; Vacchi, 2012; Mauz et al., 2015]. Diagenetic cements in the Aegean area are characterised by high Magnesian calcite (HMC), often characteristic of the marine phreatic (saturated) zone which extends over the entire swash area [e.g. Vousdoukas et al., 2007; Desruelles et al., 2009; Vacchi, 2012]. The seaward base of a beachrock slab, in its well-preserved parts that have not undergone erosion or fragmentation, represents the mean low tide of a former sea level [Kolaiti, 2019]. Different sea level stands form distinct beachrock slabs at various elevations that correspond to different generations of a fossilized palaeoshoreline [e.g. Vousdoukas et al., 2007; Desruelles et al., 2009; Vacchi, 2012; Mauz et al., 2015]. The loose, unconsolidated, sandy/sandy-gravel sediments laid on the sea bottom between two different beachrock generations represent a period of rsl change [e.g. Desruelles et al., 2009]. Determination of the cementation environment and dating of various beachrock generations makes beachrocks a reliable geomorphological indicator of the rsl change [e.g. Vousdoukas et al., 2007; Desruelles et al., 2009; Vacchi, 2012; Mauz et al., 2015; Kolaiti, 2019]. To determine the former sea level stands, the depth of the seaward base of each beachrock generation representing the low tide of a former sea level is used [Kolaiti, 2019]. Fossils, organic material or archaeological remains embedded in a beachrock are a terminus post quem for the beachrock formation, postdating the embedded material [Kolaiti, 2019].

Various ancient coastal constructions, dated from the late Neolithic to Modern Times, although now submerged, were strictly related to the sea level at the time they were in use and can therefore be used as precise archaeological indicators for the determination and dating of the former sea level stands inferred along the coast of Paros. The detailed description of the coastal landscape, including the recording of the functional features, first presented in this study, of the ancient installations that it hosted, aims at the correct interpretation of the ancient remains. Thus, it is possible to determine their relationship with the sea level at the period they were in use as well as the time limits between their construction and abandonment or destruction. 
An underwater snorkelling geological survey along the coast of Paros revealed many geomorphological and archaeological indicators of the past sea levels. During this survey, their features were recorded and depths at selected points were collected. In particular, the surveying and recording of marine notches was carried out during the GEOSWIM - Paros 2017 project, the aim of which was to survey the coastal landforms around the rocky coast of Paros [Furlani, 2012]. The depth of the base, the inward depth and opening of each marine notch were measured. A detailed mapping of the distinct beachrock generations throughout the shore of Paros Island was conducted in the present survey, using satellite images (Google Earth Pro, v. 7.3.2) and high-resolution orthophotos at a scale of 1:500 (Ktimatologio S.A.). Most of the beachrock generations recorded along the coast of Paros are intact and well-preserved in terms of erosion and fragmentation. The length, width and thickness, as well as the depth of the top and base of the seaward and landward end of each beachrock generation were measured. The average depth of repeated measurements in the same beachrock generation was used in the analysis and interpretation of data. Schematic representations of previously reported or new ancient structures were made using satellite images (Google Earth Pro, v. 7.3.2) and high-resolution orthophotos at a scale of 1:500 (Ktimatologio S.A.). The depths/elevations of particular functional features of the ancient installations were measured at selected points on the best preserved parts of the ancient structures and led us to the determination of their functional elevation with sufficient accuracy.

All measurements of depths were collected during calm sea conditions using mechanical methods (namely: a tape measure equipped with a stabilizer system on the measurement surface and a circular metallic ranging rod with conical shoe fitted at bottom and fully painted with $10 \mathrm{~cm}$ long colour bands in red and white and centimeter division) and were recorded using a PVC slate. An accuracy of $\pm 1 \mathrm{~cm}$ along the vertical is estimated [e.g. Antonioli et al., 2018]. Measurements were repeated in three different survey periods (June 1992, May 1993, May 2017-marine notches) and were updated in October 2018. To account for tides, observational data have been reduced for tide values at the time of surveys with respect to mean sea level, using tidal data from the Hellenic Navy Hydrographic Service for the closest tide-gauge station of Syros port. The effect of atmospheric pressure on the sea level was corrected using the meteorological data for the site at the time of the surveys (www.meteo.gr). Therefore, all depths reported herein correspond to depths below mean sea level (bmsl).

Error bar for depths represents deviation from the average values of multiple measurements at the same geomorphological feature. Error bar for former sea level stands refers to uncertainties in depth as estimated from marine tidal notches and beachrocks formed during the same sea level. The elevation/depth of specific features of an ancient structure with respect to the inferred mean sea level at the time when it was constructed or in use was estimated. It depends on the kind, typology and use of the archaeological sea level marker and the local tidal range [e.g. Auriemma and Solinas, 2009; Benjamin et al., 2017; Kolaiti, 2019]. Error bar for time is provided when the archaeological interpretation has not been able to determine the precise age of the ancient structure or the period that it was in use.

\section{Late Holocene sea level indicators}

\subsection{Geomorphological indicators}

\subsubsection{Marine notches}

Submerged marine tidal notches have been found on the NW coast of Paros, at Aspra Chomata near Ampelas village, and on the SW cliff of Gaidouronisi, a rocky islet a short distance off the NE coast of Paros (Figure 1c).

Two marine notches were cut into the sandstones of the molassic bedrock on Aspra Chomata coast, today both submerged. The deepest notch has an opening of $1 \mathrm{~m}$, inward depth $1.10 \mathrm{~m}$ and a base at $2.15 \mathrm{~m}$ to $2.20 \mathrm{~m}$ bmsl. The shallowest notch has an opening of $0.30 \mathrm{~m}$, inward depth $0.45 \mathrm{~m}$ and a base at $0.55 \mathrm{~m}$ to $0.60 \mathrm{~m}$ bmsl (Figure 2a).

Two submerged marine notches are also observed along the SW carbonate cliff of Gaidouronisi Islet. The base of the deepest notch is at $2.10 \mathrm{~m}$ to $2.13 \mathrm{~m} \mathrm{bmsl}$, has an opening of $0.59 \mathrm{~m}$ to $0.90 \mathrm{~m}$ and inward depth 0.33 to 0.53 $\mathrm{m}$. The shallowest notch has an opening of $0.30 \mathrm{~m}$ to $0.59 \mathrm{~m}$, inward depth $0.19 \mathrm{~m}$ to $0.53 \mathrm{~m}$ and a base at $0.37 \mathrm{~m}$ to $0.55 \mathrm{~m}$ bmsl (Figure $2 \mathrm{~b}$ ).

In summary, two marine tidal notches were identified along the rocky coast of Paros: the base of the deepest notch is at an average depth of $2.15 \pm 0.05$ and of the shallowest at $0.45 \pm 0.10 \mathrm{~m}$ bmsl (Figure $4 \mathrm{a}$ ). 


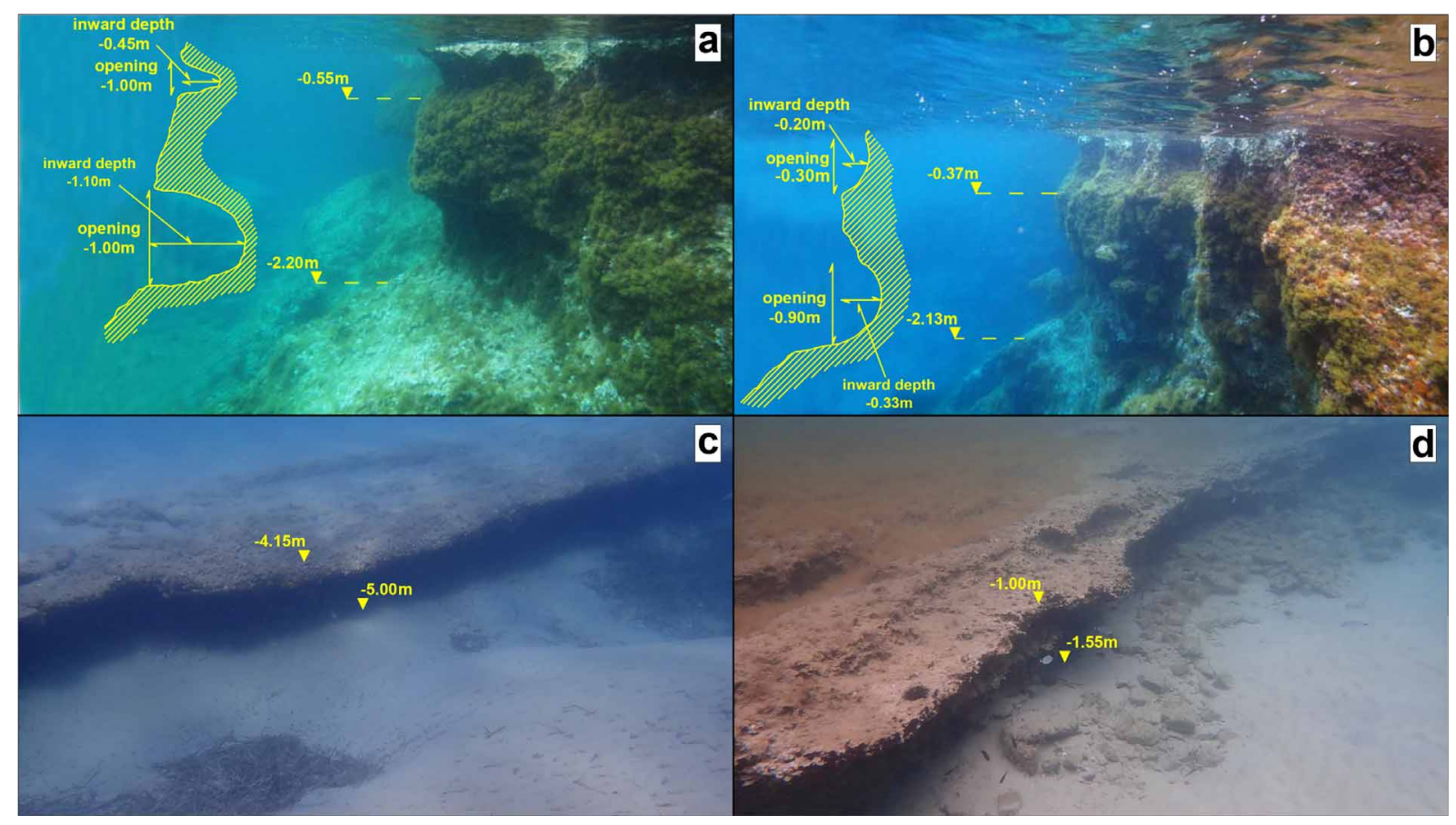

Figure 2. Submerged marine notches on the rocky coast of: (a) Aspra Chomata and (b) Gaidouronisi Islet (NE Paros) GEOSWIM - Paros 2017 project (photo from GEOSWIM - Paros 2017 project). Submerged beachrocks: (c) Logaras Bay (generation I) and (d) Martselo coast (generation IV).

\subsubsection{Beachrocks}

The systematic measurement and mapping of beachrocks at four locations along the coast of Paros (Figure 1c) enabled us to define five distinct beachrock generations (I, II, III, IV and V) that were formed during five different sea level stands. Three distinct beachrock generations were also identified at a fifth location (Tsoukalia) on the eastern coast of Paros (Figure 1c). Since the beachrocks are highy fragmented, poorly preserved and shifted from their original position, their depths are not representative and therefore were not taken into consideration.

The earliest beachrock generation (I) was found in Logaras Bay at $4.90 \pm 0.10 \mathrm{~m}$ bmsl. It is a slab $113 \mathrm{~m} \mathrm{long}, 20 \mathrm{~m}$ wide and $0.85 \mathrm{~m}$ thick (Figures 2c, 3b). The next beachrock generation (II) was found in the bays of Logaras and Molos and on the Martselo coast at $3.50 \pm 0.20 \mathrm{~m}$ bmsl. The length of the beachrock slabs varies between $108 \mathrm{~m}$ and $262 \mathrm{~m}$, with a width of between $17 \mathrm{~m}$ and $30 \mathrm{~m}$ and thickness between $0.30 \mathrm{~m}$ and $1.50 \mathrm{~m}$ (Figures $3 \mathrm{a}, \mathrm{b}, \mathrm{c}$ ). The subsequent beachrock generation (III) develops along the Martselo coast for a total length of $100 \mathrm{~m}$, with a width of $8 \mathrm{~m}$ and a thickness of $0.65 \mathrm{~m}$. Its seaward base was measured at $2.55 \pm 0.15 \mathrm{~m}$ bmsl (Figure 3c). The following beachrock generation (IV) was found in the bays of Logaras and Molos and on the Martselo coast at $1.35 \pm 0.20 \mathrm{~m}$ bmsl. The length of the beachrock slabs varies between $130 \mathrm{~m}$ and $203 \mathrm{~m}$, with a width of between $14 \mathrm{~m}$ and $30 \mathrm{~m}$ and thickness between $0.20 \mathrm{~m}$ and $0.60 \mathrm{~m}$ (Figures $2 \mathrm{~d}, 3 \mathrm{a}, \mathrm{b}, \mathrm{c}$ ). The most recent beachrock generation $(\mathrm{V})$ was found on the coast of Pounda at $0.80 \pm 0.10 \mathrm{~m}$ bmsl. It has a length of $42 \mathrm{~m}$, with a width of $3.50 \mathrm{~m}$ and thickness of $0.30 \mathrm{~m}$ (Figure $3 \mathrm{~d}$ ).

The cements of the beachrocks of Paros reflect diagenesis within the intertidal environment. Microscopic studies of thin sections of samples from the submerged beachrocks [Karkani et al., 2017] revealed well-rounded grains, bioclasts (forams and gastropods) and early intertidal cement between grains. The early intertidal cements were mainly characterised by isopachous radiaxial fibrous high magnesian calcite (HMC) crystals or small bladed isopachous fringe of limpid and contiguous HMC crystals. Evidence of micritic filling including internal sediments and peloidal cement was also observed, generally following a first fringe of early intertidal cement [Karkani et al., 2017].

Data on each beachrock generation surveyed along the coast of Paros Island are presented in Table 1 and plans of the submerged beachrocks are shown in Figure 3. In Figure 4a, the average depths of the base of the seaward end of each beachrock generation and the base of tidal notches for each survey location are shown. Error bars refer to the uncertainties in depths as estimated from multiple measurements at the same geomorphological feature. 


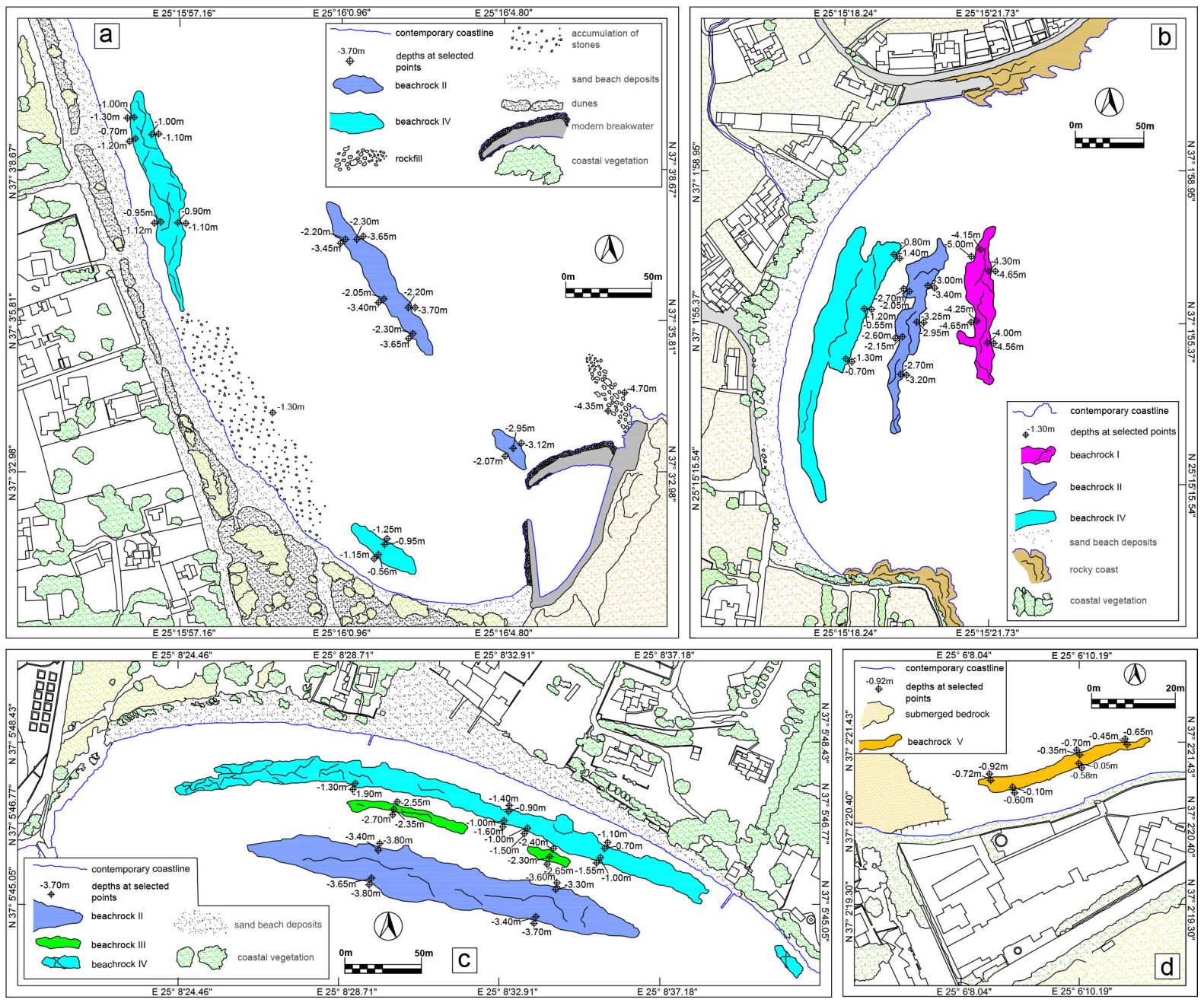

Figure 3. Beachrock generations: (a) Molos Bay, (b) Logaras Bay, (c) Martselo coast, (d) Pounda coast.
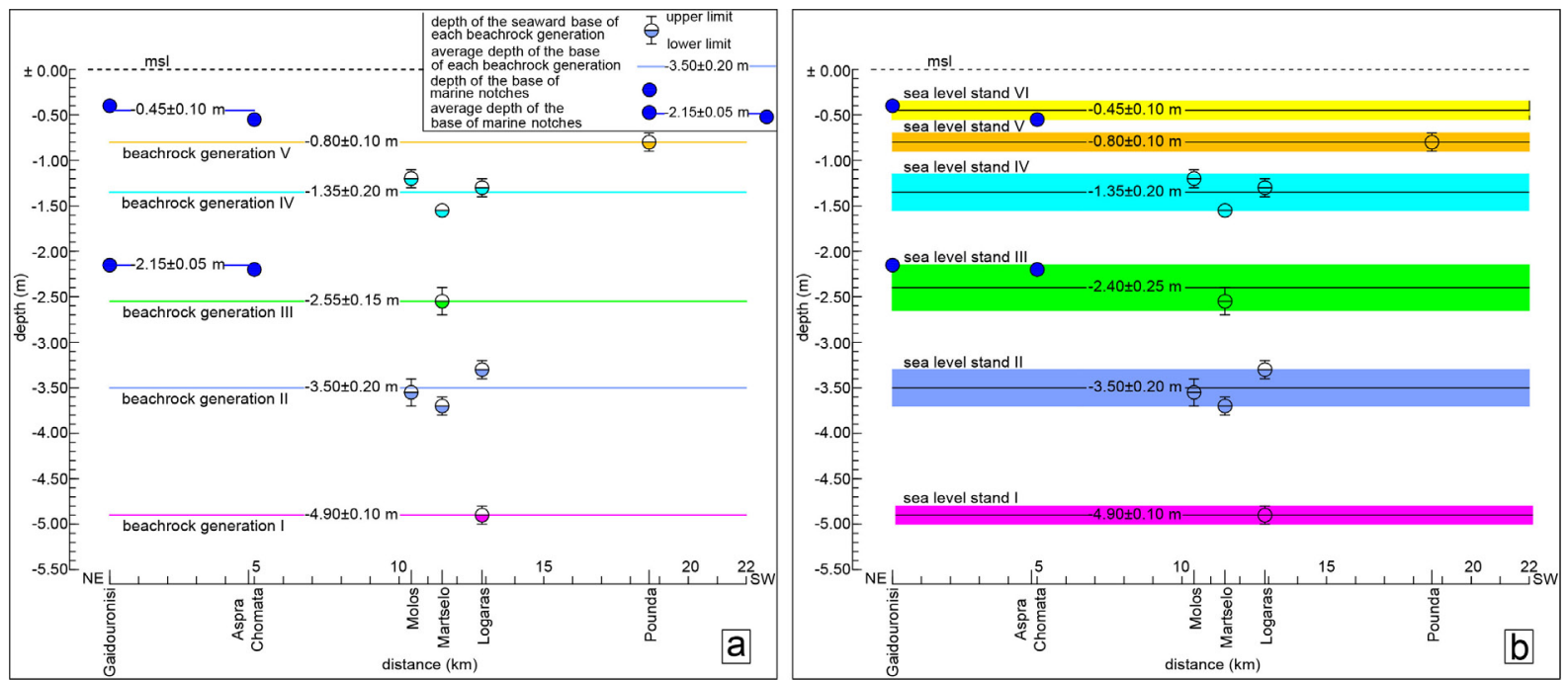

Figure 4. (a) Average depths of the seaward base of each beachrock generation and the base of marine notches identified along the coast of Paros. (b) Sea level stands deduced from the depths of the geomorphological indicators. (msl: mean sea level). 


\begin{tabular}{|c|c|c|c|c|c|c|c|c|c|c|c|}
\hline \multirow{3}{*}{ Location } & \multirow{3}{*}{ Coordinates } & \multicolumn{10}{|c|}{ Elevation bmsl (m) of beachrock generations } \\
\hline & & \multicolumn{2}{|c|}{ (I) } & \multicolumn{2}{|c|}{ (II) } & \multicolumn{2}{|c|}{ (III) } & \multicolumn{2}{|c|}{ (IV) } & \multicolumn{2}{|c|}{ (V) } \\
\hline & & top & base & top & base & top & base & top & base & top & base \\
\hline Pounta & $\begin{array}{l}37^{\circ} 02 ' 21.25^{\prime \prime N} \\
25^{\circ} 06^{\prime} 09.96^{\prime \prime}\end{array}$ & & & & & & & & & 0.70 & $0.80 \pm 0.10$ \\
\hline Logaras & $\begin{array}{l}37^{\circ} 01^{\prime} 56.48^{\prime \prime N} \\
25^{\circ} 15^{\prime} 16.66^{\prime \prime E}\end{array}$ & $4.15 \pm 0.15$ & $4.90 \pm 0.10$ & $2.85 \pm 0.10$ & $3.30 \pm 0.10$ & & & $0.55 \pm 0.05$ & $1.30 \pm 0.10$ & & \\
\hline Molos & $\begin{array}{l}37^{\circ} 03^{\prime} 05.72^{\prime N} \mathrm{~N} \\
25^{\circ} 16^{\prime} 02.53^{\prime \prime}\end{array}$ & & & 2.20 & $3.55 \pm 0.15$ & & & 0.95 & $1.20 \pm 0.10$ & & \\
\hline Martselo & $\begin{array}{l}37^{\circ} 05^{\prime} 48.14^{\prime \prime} \mathrm{N} \\
25^{\circ} 08^{\prime} 31.24^{\prime \prime} \mathrm{E}\end{array}$ & & & 3.40 & $3.70 \pm 0.10$ & 2.40 & $2.55 \pm 0.15$ & 1.00 & $1.65 \pm 0.15$ & & \\
\hline Mean eleva & tion bmsl (m) & $4.90=$ & \pm 0.10 & $3.50 \pm$ & \pm 0.20 & 2.5 & \pm 0.15 & $1.35 \pm$ & \pm 0.20 & 0.8 & \pm 0.10 \\
\hline
\end{tabular}

Table 1. Elevations of the seaward top and base of each beachrock generation along the coast of Paros. All elevations are corrected for tide and pressure at the time of survey (bmsl: below mean sea level).

\subsection{Archaeological indicators}

\subsubsection{The Late Neolithic settlement of Saliagos}

The Neolithic settlement of Saliagos lies on the western part of the Saliagos Islet. The rocky islet is located at the northern end of the Paros-Antiparos Strait and is the intermediate of three small islands that almost form a straight line: Magrines Island $\sim 400 \mathrm{~m}$ to the north, and Revmatonisi $\sim 200 \mathrm{~m}$ to the south (Figure 1c). Saliagos covers an area of $8,000 \mathrm{~m}^{2}$, rises to a height of less than $5 \mathrm{~m}$ above the present sea level and, on its NW side, is bordered by a $3 \mathrm{~m}$-high sheer cliff falling to the sea. The depth of the rocky seabed between Saliagos and Revmatonisi, and that in the Paros-Antiparos Strait, just to the south of Revmatonisi, does not exceed $5 \mathrm{~m}$ (Figures 1c, 5a). There is no source of fresh water on Saliagos [Morrison, 1968], but there is an undersea fresh-water spring off the west side of Revmatonisi whose location would then have been above sea level [Evans and Renfrew, 1968]. It is remarkable that there is almost no soil-cover left on the three islands, the exception being the southern part of Saliagos where soil is preserved to a depth sometimes exceeding $2 \mathrm{~m}$ [Evans and Renfrew, 1968].

The study of the pottery and other small finds places the Saliagos culture in the transition from Middle to Late Neolithic in mainland Greece, within the range of 4300 BC to 3700 BC [Zafeiropoulos, 1960; Evans and Renfrew, 1968]. Five radiocarbon datings (one of soil rich in organic matter and four from shells of the large bivalve Spondylus gaederopus) fall within this time range (4408 \pm 76 BC $\div 3766 \pm 85$ BC) [Evans and Renfrew, 1968]. The sequence of dates is in conformity with the Saliagos stratigraphy, as revealed by the archaeological excavations [Evans and Renfrew, 1968].

No evidence of burials has been found in Saliagos and it is very possible that some sort of cemetery, perhaps on the slopes of the promontory, has been destroyed or submerged [Evans and Renfrew, 1968]. Abundant remains of sheep, goats, cattle and pigs show clearly that mixed farming consituted the basis of life here, while no convincing evidence of hunting has been found. Large quantities of fishbones, mainly of tunny and shellfish but even a cuttlefish guard, offered a remarkable insight into the diet of the prehistoric islanders. No fish-hooks have been found in Saliagos. The shallow and narrow configuration of the bays at Saliagos may have been favourable for fishing by driving fish ashore with nets and boats and then spearing them with obsidian points [Evans and Renfrew, 1968]. 
An important ancient technical work is the submerged elongate rockfill, located about $800 \mathrm{~m}$ south of the northern insular complex of Paros-Antiparos Strait and $200 \mathrm{~m}$ south of the pier of Antiparos. Starting at a distance of $37 \mathrm{~m}$ off the contemporary coast is directed NNW-SSE towards the coast of Paros (Figure 5a). The rockfill has a total length of about $700 \mathrm{~m}$ and appears to be continouous for some $250 \mathrm{~m}$ from its beginning on Antiparos coast, while for about $450 \mathrm{~m}$ towards Paros is distinguished in parts. It has a width of 3-4 $\mathrm{m}$ and a maximum height of 2 $\mathrm{m}$. It's top and base are at a maximum depth of $3 \mathrm{~m}$ and $5.20 \mathrm{~m}$ bmsl, respectively (Figure 5a).

The extensive farming and craft activity at Saliagos during its short occupation of 200 to 400 years, as the archaeological survey has revealed [Evans and Renfrew, 1968], could not be limited to such a small islet, lacking planation, fresh water and vegetation. A wider area to the south, as the bathymetry of the northern part of ParosAntiparos Strait implies, which included Revmatonisi to the south and was joined to the coast of the two islands on either side, forming a "transit corridor", could justify the establishment and development of the Late Neolithic settlement (Figure 5b). According to the palaeogeographic reconstruction of the coast (Figure 5b), the ancient rockfill, today submerged, was placed at the southernmost edge of the then land.
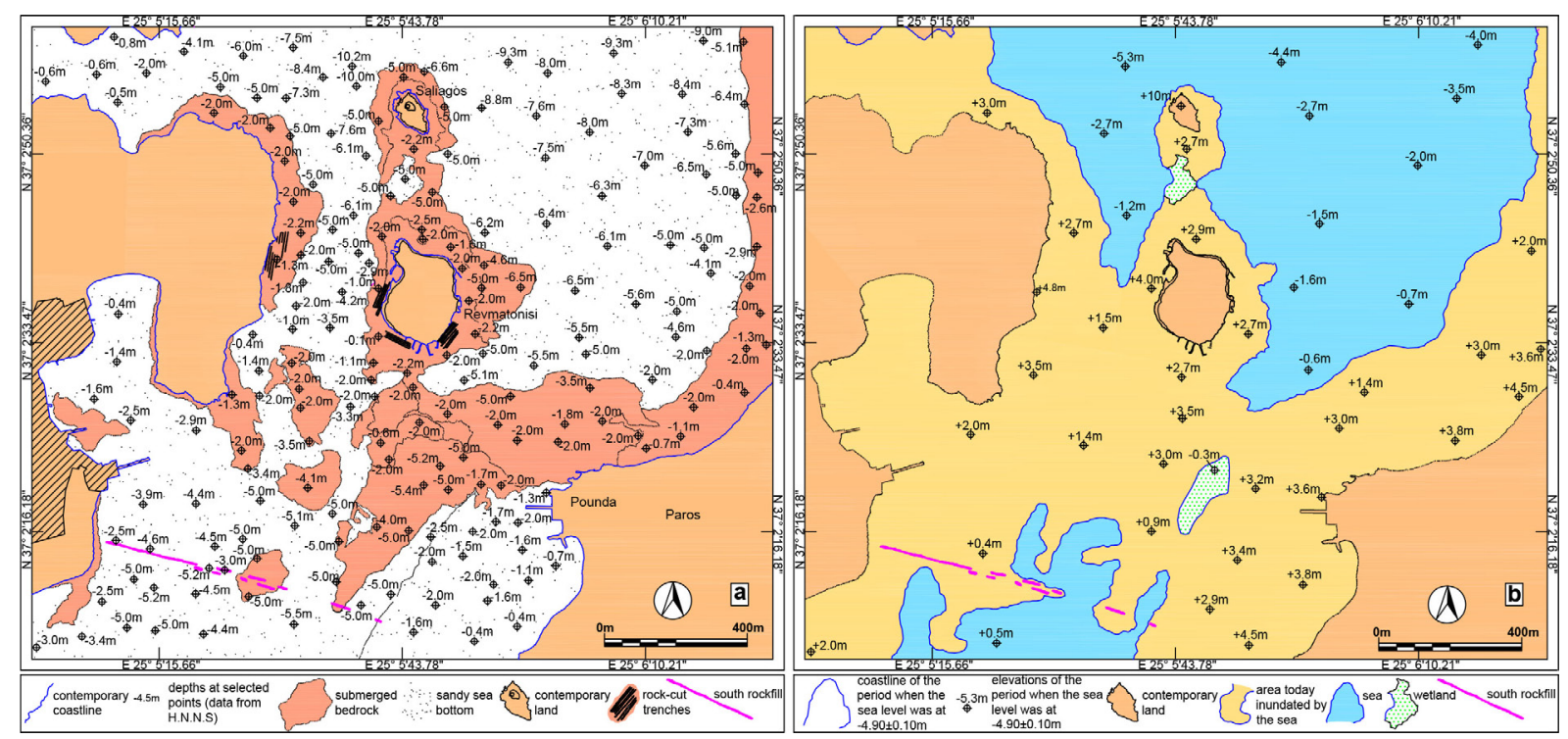

Figure 5. (a) Bathymetric map of the northern section of the Paros-Antiparos Strait (depths from H.N.H.S). (b) Palaeogeographic reconstruction of the northern section of the Paros-Antiparos Strait when the sea level was at $4.90 \pm 0.10 \mathrm{~m}$ bmsl.

\subsubsection{The Geometric breakwater of Agios loannis Detis}

At the NW end of Naoussa Gulf, on the hill west of the Monastery of Agios Ioannis Detis (Figure 1c), rectangular buildings of the Geometric period ( $8^{\text {th }}$ c. BC) have been revealed [Kourayos, 2015]. A rubble mound breakwater, today submerged, begins at the sharp seaward edge of the rocky hill (Figure 6). This has also been reported by Papathanassopoulos and Schilardi [1981]. The breakwater develops in an E-W direction for a length of $78.50 \mathrm{~m}$ and its width reaches $14 \mathrm{~m}$. It consists of stones ranging from $0.20 \mathrm{~m}$ to $0.60 \mathrm{~m}$ in size. Its top surface has a width of 4 $\mathrm{m}$ in the western part and widens in the eastern part, reaching $9 \mathrm{~m}$. The surface of the breakwater in the western section is from $1.20 \mathrm{~m}$ to $1.35 \mathrm{~m}$ bmsl while the eastern section gradually sinks from $1.65 \mathrm{~m}$ to $2.35 \mathrm{~m}$ bmsl at its seaward end. The depth of the sea bottom at the base of the breakwater increases from west $(2.68 \mathrm{~m})$ to east (6.05 $\mathrm{m})$. In the central part of the breakwater, a hollow was observed, the bottom of which is at $2.60 \mathrm{~m}$ bmsl. It occupies an area of $11 \mathrm{~m}^{2}$ and has an internal depth of about $1 \mathrm{~m}$ (Figure 6). It probably served for accumulating fuel to light a fire to signal the position of the breakwater and hence the settlement. 


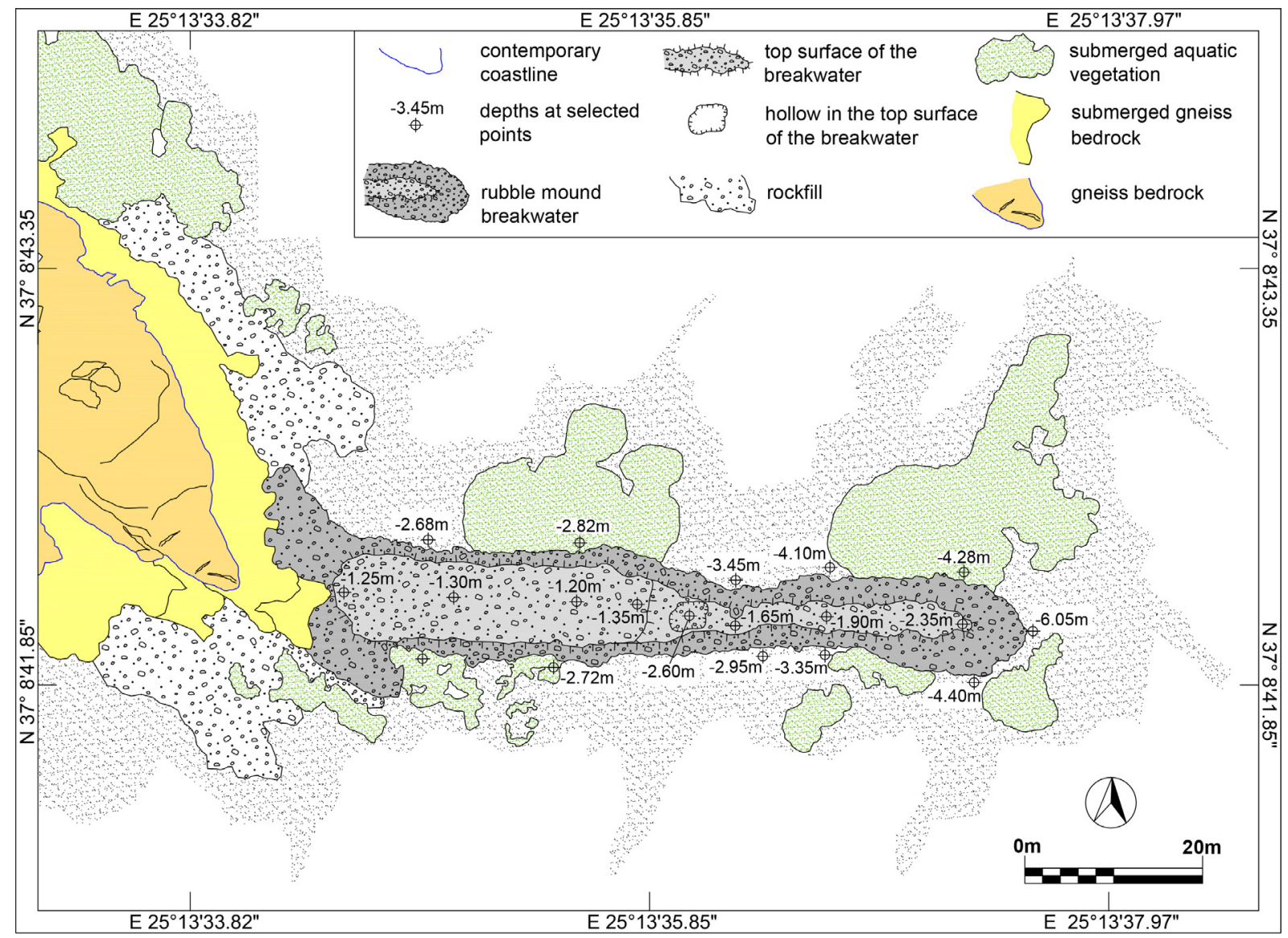

Figure 6. Plan of the rubble mound breakwater of Agios Ioannis Detis.

\subsubsection{Lighthouses, paved road, tombs and piles of stones of the Geometric or Archaic period in Zoodochos Pigi Bay}

Oikonomou Island ("Nisi Oikonomou”), in truth an islet, is located at the eastern end of Naoussa Gulf (Figure 1c) and is connected to the coast of Paros opposite through a narrow sandy strip of land, forming two small bays on both north and south sides of the strip (Figure 8a). On the SE part of Oikonomou Island, a fortified settlement, probably dated to the Geometric and Archaic period, is preserved up to the level of its foundations [Schilardi, 1973; Kourayos, 2015] (Figures 7, 8a). In the north bay (Zoodochos Pigi Bay) the depths do not exceed $3 \mathrm{~m}$, the seabed is sandy and an elongate reef of a maximum elevation of $0.50 \mathrm{~m}$ protrudes from the sea bottom only on its west side. The reef, $250 \mathrm{~m}$ long and $25 \mathrm{~m}$ wide, is located within a distance of $100 \mathrm{~m}$ from the NE coast of Oikonomou Island and follows its configuration. Two large cairn-like piles of stones lay on the reef within $42 \mathrm{~m}$ of each other. They have also been reported by Fotiou [1973], who interpreted them as maritime structures. The southern pile of stones, 1.40 $\mathrm{m}$ high and $280 \mathrm{~m}^{3}$ in volume, has an ellipsoidal base occupying an area of $290 \mathrm{~m}^{2}$. The sea bottom on its western side is at $2.55 \mathrm{~m} \mathrm{bmsl}$ and on its eastern and southern sides between $3.10 \mathrm{~m}$ and $3.20 \mathrm{~m}$ bmsl. Its top surface, of an area of $105 \mathrm{~m}^{2}$, is from $1.20 \mathrm{~m}$ to $1.80 \mathrm{~m}$ bmsl. In the NW part, a hollow of an area of $14 \mathrm{~m}^{2}$ and internal depth 0.40 $\mathrm{m}$ is observed, with its bottom at $1.60 \mathrm{~m}$ bmsl. The northern pile of stones, $1.70 \mathrm{~m}$ high and $370 \mathrm{~m}^{3}$ in volume, has an elongate oval base occupying an area of $350 \mathrm{~m}^{2}$ at the depth of $2.90 \mathrm{~m} \mathrm{bmsl}$. Its top surface, covering an area of $140 \mathrm{~m}^{2}$, is at $1.30 \mathrm{~m}$ to $1.40 \mathrm{~m}$ bmsl. A $17 \mathrm{~m}^{2}$ hollow with internal depth of $0.20 \mathrm{~m}$ is also observed on the northern side of the top surface, with its bottom at $1.40 \mathrm{~m}$ bmsl. The two large piles of stones were probably lighthouses, signaling the NE coast of Oikonomou Island, with the hollows in their surface serving to accumulate fuel for lighting fires to signal the position of the shoreline. Between the two piles of stones, rectangular carvings, most likely graves, were observed at $3 \mathrm{~m} \mathrm{bmsl}$. Another rectangular carving - also likely to have been a grave - was found at $3.25 \mathrm{~m} \mathrm{bmsl}$ between the reef and the opposite coast, where the small church of Zoodochos Pigi is situated (Figures 7, 8a). 
RSL change on Paros, N Cyclades

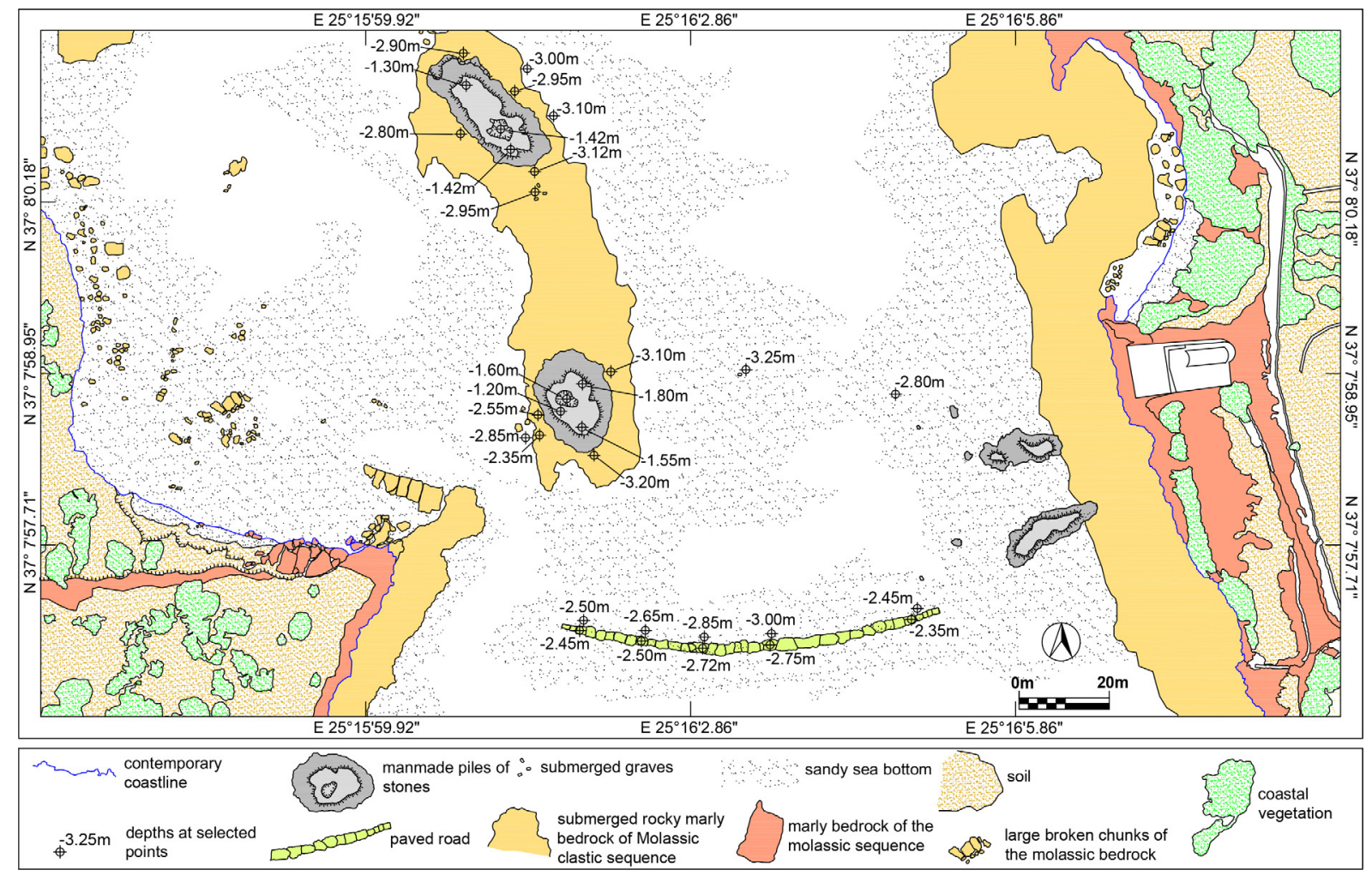

Figure 7. Plan of the northern end of Zoodochos Pigi Bay, in which the submerged structures are indicated.
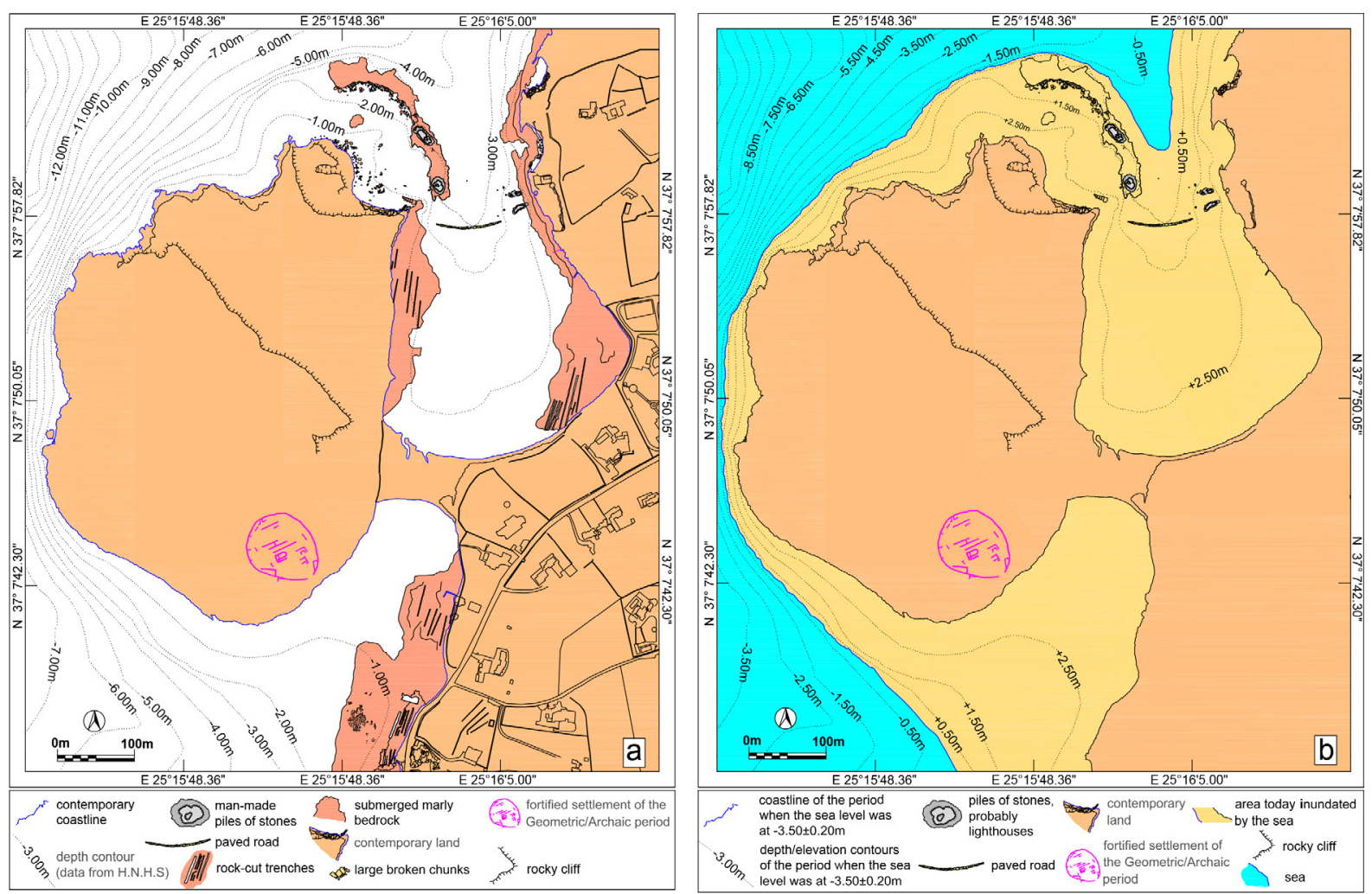

Figure 8. (a) Bathymetric map of Oikonomou Island (depths from H.N.H.S.). (b) Palaeogeographic reconstruction of Oikonomou Island when the sea level was at $3.50 \pm 0.20 \mathrm{~m}$ bmsl. 


\section{Eleni Kolaiti and Nikos Mourtzas}

Further south, within $32 \mathrm{~m}$ of the southern end of the reef, 37 large slabs, measuring from $5.50 \mathrm{~m} \times 2 \mathrm{~m}$ to 1.50 $\mathrm{m} \mathrm{x} 1 \mathrm{~m}$ and $0.20 \mathrm{~m}$ to $0.30 \mathrm{~m}$ thick, are laid on the sandy bottom in a row oriented E-W. They form a paved road that, at some time, seems to have provided communication between the two opposite shores. The slabs have been extracted from the hard crust of the marly molasse, south of Zoodochos Pigi church. They are at a maximum depth of $3 \mathrm{~m}$ bmsl with their top surface at $2.75 \mathrm{~m}$ bmsl. About $20 \mathrm{~m}$ from the easternmost end of the paved road, two rockfills transversally positioned with reference to the coastline were observed at about $1.50 \mathrm{~m}$ bmsl (Figures 7, 8a). On the northern part of Oikonomou Island, Fotiou [1973] observed an uphill road, which starting from the coast leads to an artificial plateau full of ceramics. The road is $40 \mathrm{~m}$ long and $8 \mathrm{~m}$ wide and was cut into the rock, as evidenced by the visible cutting traces on the rocky coast. This is probably the on land extension of the today submerged paved road.

Schilardi [1973] and Papathanassopoulos and Schilardi [1981], have identified ancient submerged rectangular tombs, measuring about $2 \mathrm{~m} \times 2 \mathrm{~m}$, made with slabs, and a short projecting entrance sealed with stones. During the present survey, we found these tombs on the SE side of the south bay of Oikonomou Island, $17 \mathrm{~m}$ offshore, at a depth of $1.80 \mathrm{~m}$ to $2.50 \mathrm{~m}$ bmsl (Figure $8 \mathrm{a}$ ).

\subsubsection{Ancient rock-cut trenches}

Extensive series of elongate rock-cut trenches and parallel rows of rectangular cuttings have been identified at 25 locations on and off the coast of Paros, Revmatonisi, Diplo, Antiparos and Despotiko (Figure 1c). The rock-cut trenches of Paros were first reported by Graves [1842] and Rubensohn (1901) and those on the eastern coast of Antiparos and on Revmatonisi by Evans and Renfrew [1968] and Morrison [1968]. Fotiou [1973] has described the cuttings found in Naoussa Gulf and Draganits (2009) as well as those on the northern coast of Despotiko. The cuttings in Filizi Bay and the Santa Maria area, Naoussa Gulf, Zoodochos Pigi and Lageri Bays, the areas of Pounda, Kampos, Agios Nikolaos and Voutakos in the Paros-Antiparos Strait and in the bay of Despotiko were surveyed by the Ephorate of Underwater Antiquities in 2001 [Kraounaki, 2012].

Most of the rock-cut trenches are located on the NE side of Paros, on the eastern coast of Naoussa Gulf (8 locations) and in Santa Maria Bay (2 locations) and Filizi Bay (3 locations). Others can be found on the northern part of the Paros-Antiparos Strait on the coast of both islands (3 locations on the SW coast of Paros and 2 locations on the eastern coast of Antiparos), between them on the coast of Revmatonisi Island (3 locations), and to the north of Antiparos on the coast of Diplo Island (2 locations). On the eastern coast of Paros, in Drios, only one group of elongate cuttings was identified. Additionally, on the NE coast of Despotiko Island, there is a system of rock-cut parallel trenches (Figure 1c).

The trenches were usually cut parallel to each other at a distance of $1 \mathrm{~m}$ to $8 \mathrm{~m}$, with a length ranging from 13 $\mathrm{m}$ to $140 \mathrm{~m}$ and a width of $1 \mathrm{~m}$ to $2 \mathrm{~m}$. Their orientation is mainly NE-SW (17 locations) but also NW-SE (8 locations, either parallely (22 locations) or transversally (3 locations) with reference to the palaeoshoreline. The rectangular cuttings, measuring $1.50 \mathrm{~m} \mathrm{x} 1 \mathrm{~m}$, have been identified at 4 locations, either in one row (2 locations) or in two to three parallel rows (2 locations) within $3 \mathrm{~m}$ to $4.50 \mathrm{~m}$ of each other. In some cases (3 locations), rectangular cuttings in rows were observed between the rock-cut trenches. Most of the trenches have been carved into the hard, $2 \mathrm{~m}$ thick, reddish, calcitic-clayey crust of the molassic clastic sequence of Paros.

There is still speculation among researchers about the use and the dating of these impressive rock-cut constructions. From the $19^{\text {th }}$ c. onward, several views have been expressed on their use. Graves [1842], who first produced a bythometric map of the central Cyclades, and Rubensohn [1901] suggested that the trenches served as salt-pans. Evans and Renfrew [1968] and Morrison [1968] assumed that they represent a Hellenistic field-system of vine trenches for systematic viticulture. Fotiou [1973] interpreted the cuttings in Naoussa Gulf as harbour installations and shipsheds. Berranger-Auserve [1992] suggested that the cuttings in Santa Maria were shipyards and boat installations for marble export, because the ancient roads that start from the quarries end up at the coast there. Auffray [2002], after presenting several hypotheses for the use of trenches - as grape presses for must making, or seawater tanks for immersing wine amphorae to accelerate wine ageing, or quarries, or even shipyards - finally adopted the last interpretation, despite the horizontal position of the trench floor. Kraounaki [2012] suggested that, apart from shipyards and harbour installations, all other interpretations should have been considered: buildings related to naval installations, transport systems for heavy materials (e.g. marble, wood, statues, architectural members), fish-tanks or salt-pans, viticulture systems or even rainwater drainage systems. 

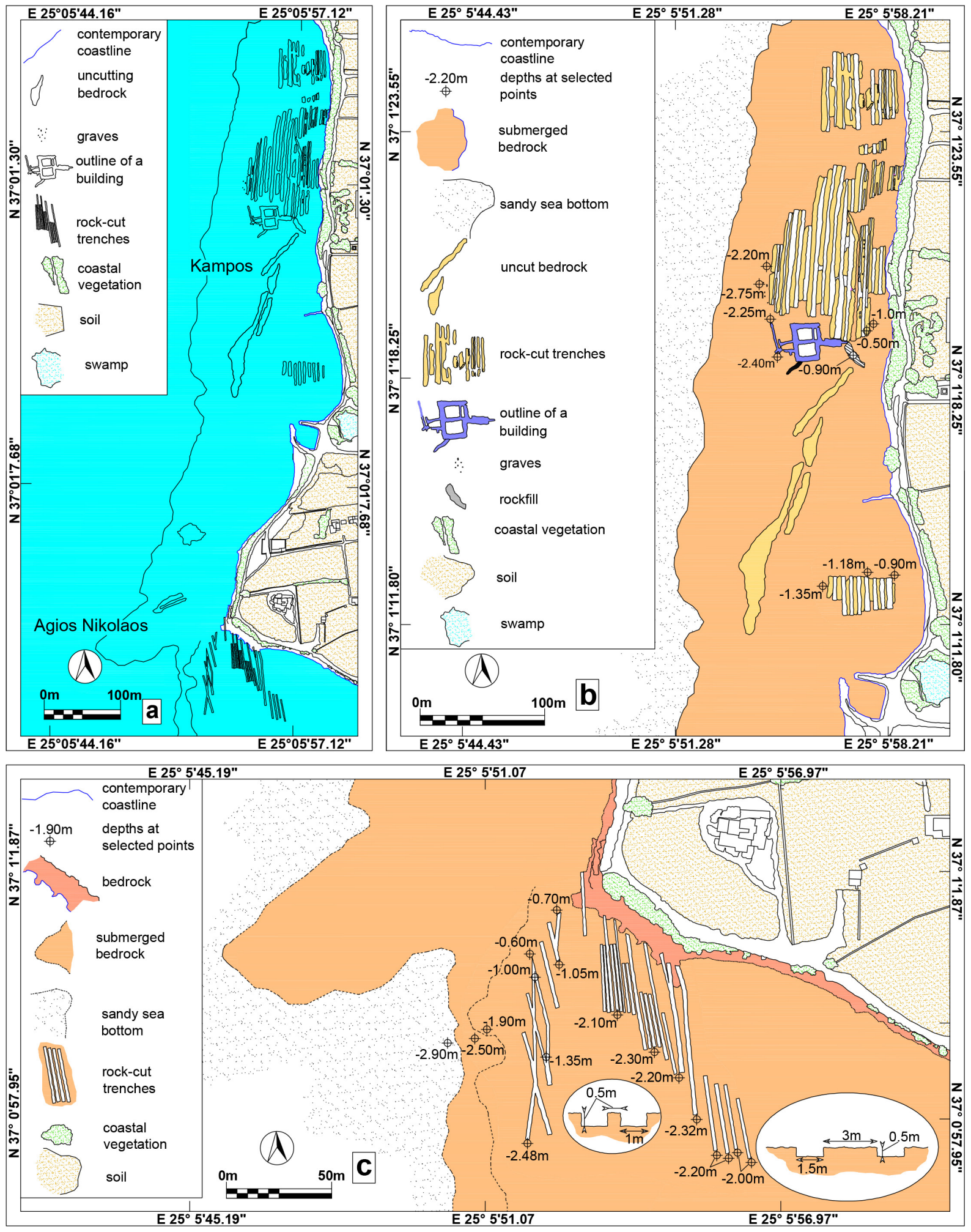

Figure 9. (a) General plan of the submerged rock-cut trenches on the Kampos coast and on the Agios Nikolaos coast (West Paros). (b) Plan of the submerged rock-cut trenches, building and graves on the Kampos coast. (c) Plan of the submerged rock-cut trenches on the Agios Nikolaos coast. 


\section{Eleni Kolaiti and Nikos Mourtzas}

The proposed interpretation that the rock-cut trenches were used in antiquity for systematic viticulture would appear to be the most plausible. The natural environment of Paros favoured, and still favours, the cultivation of vine. The technique of planting vines by digging trenches in soil or cutting them in rock during antiquity is mentioned by ancient writers, e.g. Pliny, Strabo, Theophrastus, Xenophon, Palladius, Palladius (II.10.1), Columella (De re Rustica, III, 13) and is reported by findings from archaeological excavations [e.g. Amouretti, 1988, 1992; Karali and Mavrides, 1998; Lilimpaki-Akamati, 1998; Brun, 2003; Scarlatidou, 2004; Vordos, 2005]. The depth of trenches would have been $0.70 \mathrm{~m}$ and a path $-3 \mathrm{~m}$ to $5.50 \mathrm{~m}$ wide - would have been left between them to allow carriages to pass. Concerning the orientation of the vineyard, Columella (De re Rustica, III, 12, 5-6) suggested that, in very hot areas such as Egypt, it is advisable for them to be oriented only to the north. On coastal vineyards, the favourable effect of the sea is due to the high thermal inertia of seawater, i.e. its capacity for heat storage. Therefore, the vineyard's proximity to the sea blunts the daytime temperature peaks, thus creating gentler mesoclimate conditions than those of continental areas located at the same geographical latitude and altitude. On the other hand, the constant fresh and humid sea breeze blowing through coastal terroirs during the hot hours of the day mitigates the ambient temperature and improves lighting conditions, thus serving the gentle ripening of grapes [Coastal-terroirs].

Evans and Renfrew [1968] and Morrison [1968] dated the trenches to the Hellenistic period. Specifically for the area of Voutakos, the Hellenistic dating could be related to the concentration of Classical/Hellenistic ceramics found north and west of the church of Agios Georgios [Vionis, 2006]. Auffray [2002] associated them with activities of the Geometric period around Oikonomou Island. Kraounaki [2012], points out that their dating - in the absence of ceramics or evidence of any type of masonry - remains problematic, and hence their use may or may not be simultaneous, thus implying that they might belong to different periods.

With the exception of three locations, where the rock-cut trenches today are on land, they are all submerged from the contemporary coastline up to a depth of $2.50 \mathrm{~m}$. Most of them are of considerable length and found on the WSW side of Paros, on the coast of Voutakos, Agios Nikolaos and Kampos (Figures 1c, 9a).

Three groups of trenches were found on the coast of Kampos (Figure 9b). The southernmost group, some $50 \mathrm{~m}$ to the north of the small fishing port of Kampos, consists of 8 parallel trenches $3 \mathrm{~m}$ to $3.50 \mathrm{~m}$ apart, $30 \mathrm{~m}$ long and $3 \mathrm{~m}$ wide each, located between the depths of $0.95 \mathrm{~m}$ and $1.35 \mathrm{~m}$ bmsl. At a distance of $200 \mathrm{~m}$ to the north, the second group, consisting of 17 parallel trenches, stretches for $135 \mathrm{~m}$ in a NNE-SSW direction from the contemporary coastline to $90 \mathrm{~m}$ offshore at the depth of $2.20 \mathrm{~m} \mathrm{bmsl}$. They are $1 \mathrm{~m}$ to $2.50 \mathrm{~m}$ wide and have an internal depth of $0.50 \mathrm{~m}$. At the south end of this group of trenches, the ruins of a large building were identified, occupying an area of $1500 \mathrm{~m}^{2}$, with abundant potsherds on its floor mixed with the collapsed masonry. The building probably served craft and storage needs associated with the use of the rock-cut trenches. It was most likely a warehouse, where large pithoi were placed for wine fermentation and storage [e.g. Nikolantonakis and Amoiridou, 2011]. The last and deepest visible trace of the building is at $2.40 \mathrm{~m} \mathrm{bmsl}$, while to the northwest a large number of rectangular cuttings with a slab cover on the top, probably graves, measuring about $1.50 \mathrm{~m}$ x $0.70 \mathrm{~m}$ each, were tracked up to a depth of $2.75 \mathrm{~m}$. The third group is located some $30 \mathrm{~m}$ further north and consists of at least 11 trenches (Figure $9 \mathrm{~b}$ ).

At a distance of about $300 \mathrm{~m}$ to the south of Kampos, on the south coast of the promontory where the chapel of Agios Nikolaos is situated (Figure 9c), a group of 20 parallel trenches $1 \mathrm{~m}$ to $3 \mathrm{~m}$ apart was found. They stretch in a NNW-SSE direction, with a length ranging from $27 \mathrm{~m}$ to $70 \mathrm{~m}$, a width of $1.50 \mathrm{~m}$ and an internal depth of $0.50 \mathrm{~m}$, with their floor dipping $1^{\circ}$ southward. In the southern part, they reach a depth of $2.20 \mathrm{~m} \mathrm{bmsl}$. Some $20 \mathrm{~m}$ west of these, there is a group of crossed trenches, with their deepest trace at $2.48 \mathrm{~m} \mathrm{bmsl}$.

\subsubsection{Roman building complex in Paroikia Gulf}

This is a building complex submerged $15 \mathrm{~m}$ offshore the SE coast of Paroikia Gulf, $80 \mathrm{~m}$ SE of the Paroikia marina (yacht port) (Figure 1c). It was first reported by Rubensohn [1901, 1949] and later by Papathanassopoulos and Schilardi [1981]. It occupies an area of at least $800 \mathrm{~m}^{2}$ (Figure 10). It runs for $35 \mathrm{~m}$ at an angle to the contemporary shoreline, with its central axis in a NE-SW direction. A transversal NW-SE corridor, $15 \mathrm{~m}$ long and $2 \mathrm{~m}$ wide, divides the building into two separate sections: NE and SW. The latter consists of 11 rectangular rooms, varying in area from $4 \mathrm{~m}^{2}$ to $17 \mathrm{~m}^{2}$. On their floor, ceramic tiles are preserved in-situ. A square tank of side $1.70 \mathrm{~m}$, coated with hydraulic mortar, was identified on the northern side of the SW section. The NE section consists of at least 7 rooms of different size, the largest of which is $60 \mathrm{~m}^{2}$. All along the seaward - preserved - side of the building, there is a $40 \mathrm{~m}$-long 
corridor $1.50 \mathrm{~m}$ wide. The most impressive finding is a preserved marble frame with ceramic conduits, part of the tank's drainage system. The walls have a thickness of $0.40 \mathrm{~m}$ to $1.30 \mathrm{~m}$ and in large parts of the building stand up to $0.30 \mathrm{~m}$ in height. They are built of rough stones, ceramic tiles and bricks, bound with mortar. It shows the same typology as those of other residences, workshops or farmhouses found on Paros [e.g. Floga site, Kourayos, 2015] that date back to the Roman period $\left(146 \mathrm{BC}-4^{\text {th }} \mathrm{c}\right.$. AD).

The building complex is now completely submerged, with sections of the paved floor at $1.20 \mathrm{~m}$ bmsl and external masonry at $1.60 \mathrm{~m}$. The last trace of paving and foundations was identified $65 \mathrm{~m}$ offshore at $1.75 \mathrm{~m}$ bmsl and either belongs to the building or is a remnant of the road that passed in front of it (Figure 10). Furthermore, the positioning of the building with respect to the palaeoshoreline (Figure 10) implies that here may have been the coastal section of the Roman road, which started from the Ekatontapyliani area, passing through the Roman cemetery [Zafeiropoulou, 1998; Kourayos, 2015] and ending in the workshops area (called "Magazakia"), to which the building complex most likely belongs.

Two large piles of stones, of circular base about $6 \mathrm{~m}$ in diameter, were found submerged on the seafloor some $30 \mathrm{~m} \mathrm{SW}$ of the building complex. They were constructed along the shoreline on the exposed seafront of the workshops either to protect it against the waves (protective rockfills) or to signal the then shoreline (cairn-like landmark). Whatever the case, their current position defines the coastline of the period in which they were constructed [Kolaiti, 2019]. The seaward base of the northern pile of stones is at $2.35 \mathrm{~m} \mathrm{bmsl}$ and its top at $1.70 \mathrm{~m}$ bmsl (Figure 10).

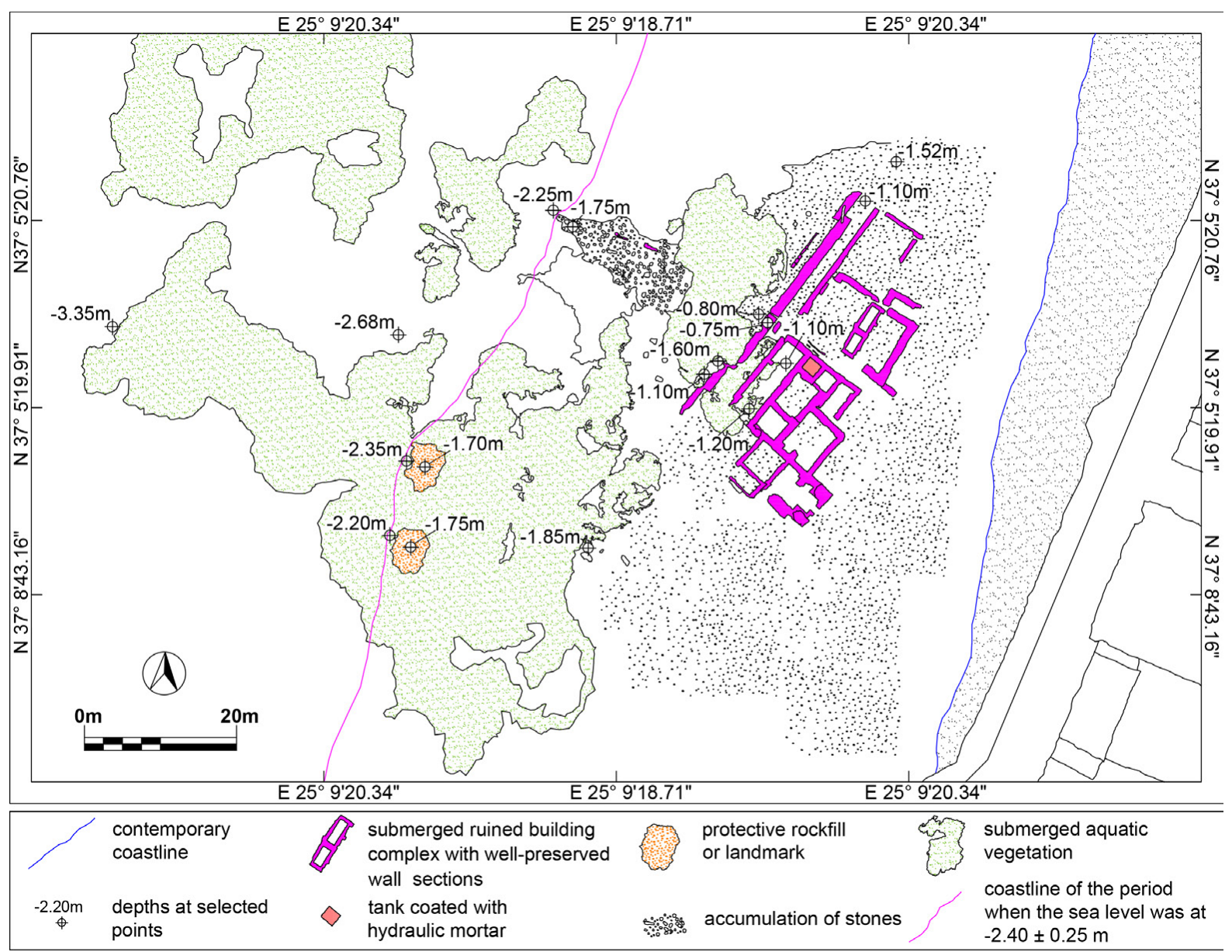

Figure 10. Plan of the submerged building complex in Paroikia Gulf. 


\section{Eleni Kolaiti and Nikos Mourtzas}

\subsubsection{Roman breakwater on Krotiri coast}

The ancient rubble mound breakwater on Krotiri coast, on the NW side of Paroikia Gulf (Figure 1c), was first shown in the map made by Roux [1804], in which a depth of $6 \mathrm{ft}(\sim 1.83 \mathrm{~m})$ is also noted just to the west of the breakwater. The ancient breakwater was later reported by Schilardi [1981] and Papathanassopoulos and Schilardi [1981]. Much later, Evelpidou et al. [2018], ignoring Roux's map [1804], doubted whether the mole was ancient and reiterated the speculations of "the locals that the breakwater is a work of Nazis during the German occupation of the island in World War II".

The breakwater starts about $7 \mathrm{~m}$ from the sandy-gravely coast and runs SE for $102 \mathrm{~m}$ (Figure 11). Its maximum breadth reaches $19 \mathrm{~m}$ at the base, while at the top surface this does not exceed $9 \mathrm{~m}$. In the central part of the breakwater, a hollow measuring $9 \mathrm{~m} \mathrm{x} 3 \mathrm{~m}$ and approximately $1 \mathrm{~m}$ deep was observed. The size of the rubblestones, carefully set forming the breakwater, ranges from $0.20 \mathrm{~m}$ to $0.60 \mathrm{~m}$. The depth of the top of the breakwater varies between $1.10 \mathrm{~m}$ and $1.35 \mathrm{~m}$, with the exception of its approximately $20 \mathrm{~m}$ long seaward end, where it increases to $1.60 \mathrm{~m}$. Correspondingly, the depth at the base of the breakwater gradually increases from $1.40 \mathrm{~m}$ near the coast up to $4.10 \mathrm{~m}$ at its seaward end (Figure 11).

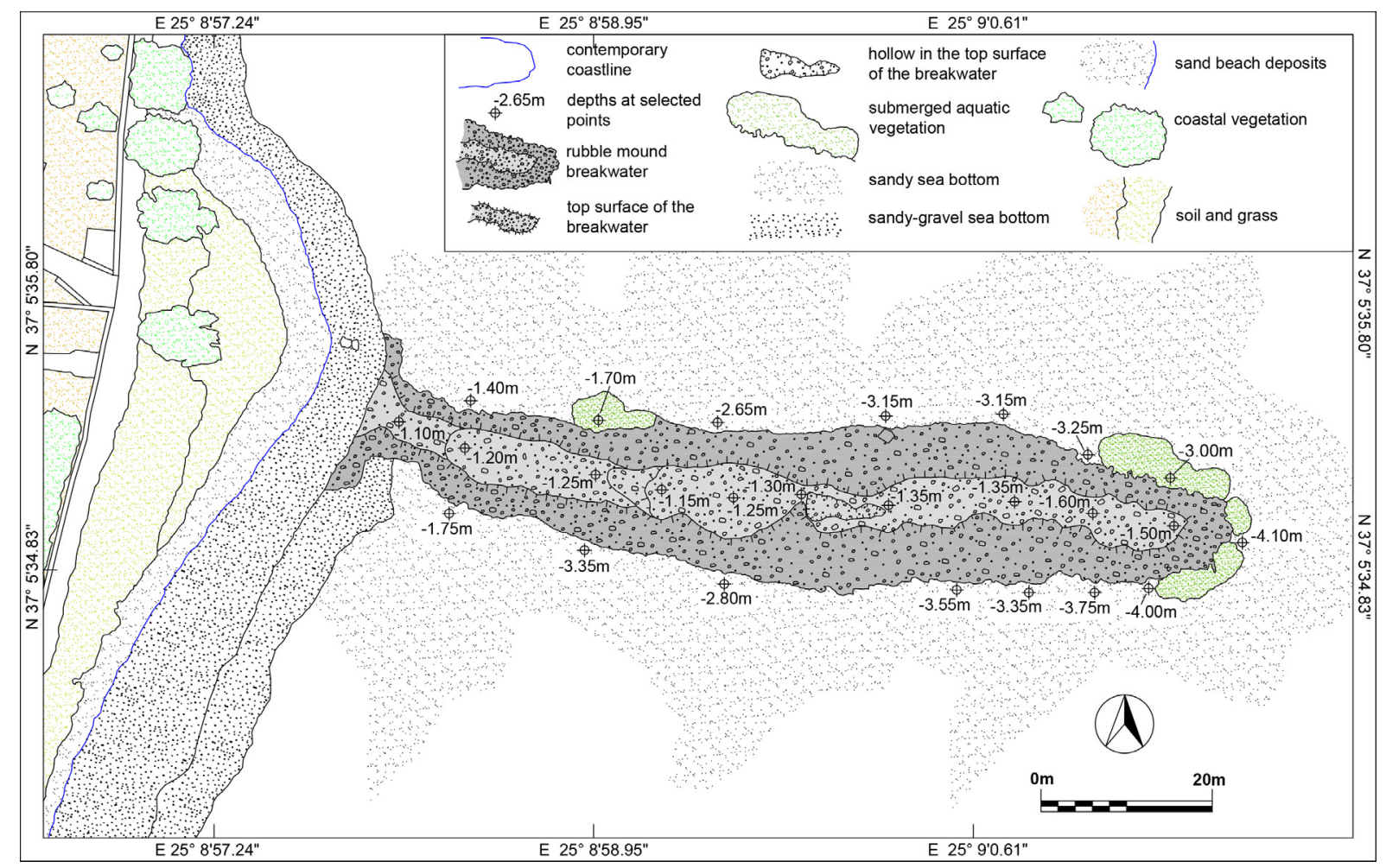

Figure 11. Plan of the rubble mound breakwater of Krotiri in Paroikia Gulf.

\subsubsection{Quarry on Tigani Islet}

The quarryscape is located at the southernmost tip of Tigani Islet, in the middle of the Tigani-Panteronisi Strait (Figures 1c, 12). The quarry has been excavated out of aeolianites, applying the typical timeless quarrying technique that has been used during antiquity. Remains of systematic quarrying activity are still visible there, such as: the quarry face and floor, steps, trenching and undercuts, blocks left in place, stoneworking toolmarks, etc. The main quarry face is located near the shore, occupying an area of about $300 \mathrm{~m}^{2}$. Its floor is at $0.80 \mathrm{~m}$ bmsl. Quarrying traces can be seen in two more sections now under the sea; the furthest one is located $20 \mathrm{~m}$ from the shore and its floor is at $1.50 \mathrm{~m}$ bmsl (Figure 12). 


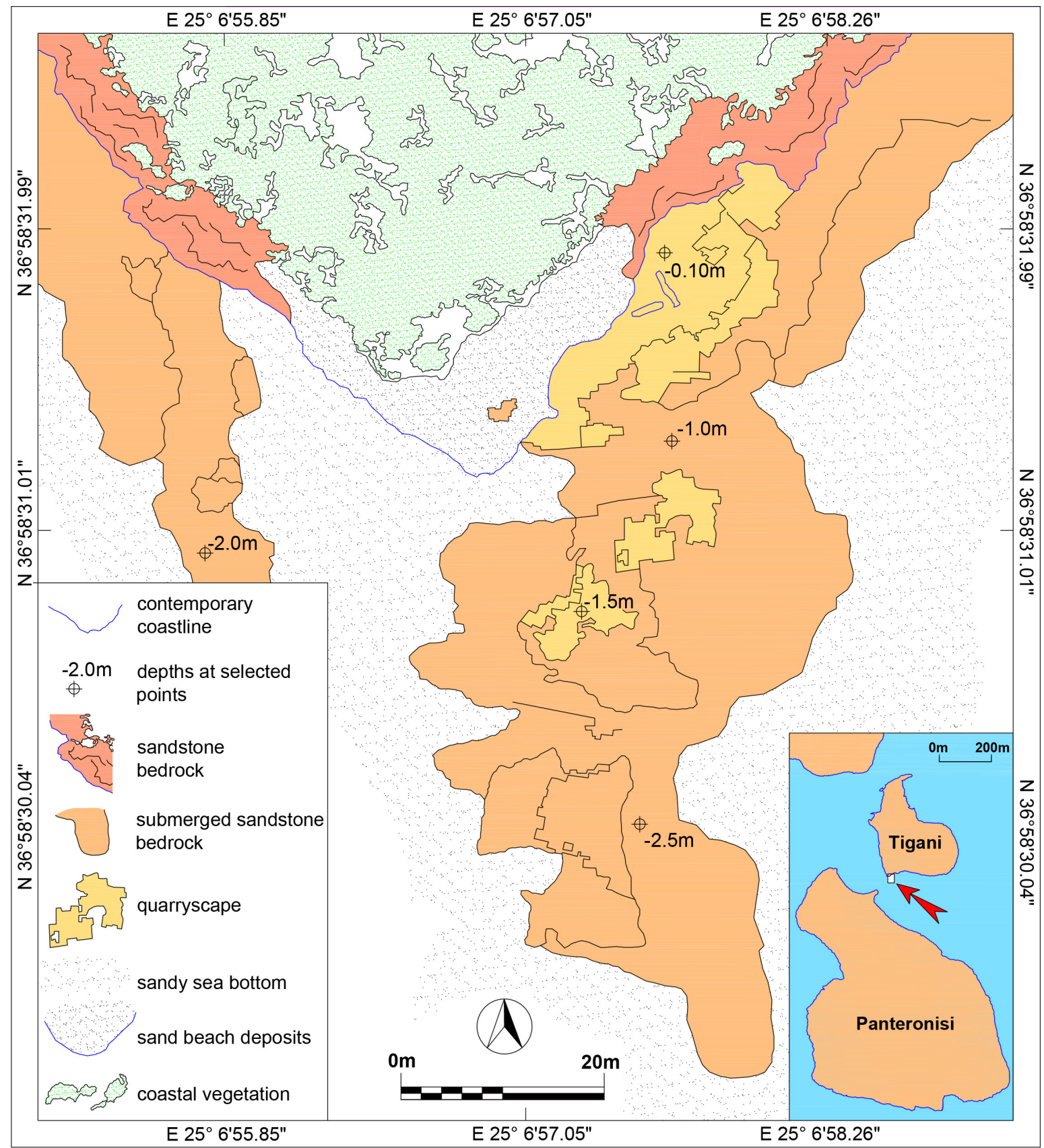

Figure 12. Plan of the submerged quarry on the south coast of Tigani Islet.

\subsubsection{The Venetian castle of Naoussa}

The castle of Naoussa (Figure 1c) was built in the late $13^{\text {th }}$ to the early $14^{\text {th }} \mathrm{c}$. A circular tower with firing apertures (“Castelli”) was added at the entrance of the port for defensive purposes around 1500 [Christopoulou, 1984; Vionis, 2006]. Arranged around a small bay, the fortified town of Naoussa with its small harbour sheltered by moles-seawalls already existed in the $15^{\text {th }}$ c., according to the description of Buondelmonti (1420 [1897]).

The Castelli was founded on a rocky outcrop, $115 \mathrm{~m}$ long and $75 \mathrm{~m}$ wide, that develops in a NE-SW direction. Its top surface occupies an area of 2,350 $\mathrm{m}^{2}$ and, apart from a section of the northern part that protrudes from the sea, seems to have been flattened (Figures 13a, b). At its northern end, it is bordered by a $2 \mathrm{~m}$-high sheer cliff. The foundations and part of the superstructure of the Castelli, apparently built on land, are currently at $0.66 \mathrm{~m}$ to 0.78 $\mathrm{m}$ bmsl (Figures 13a, b). The seawall, attached to the eastern side of the Castelli and built with stones bonded with 


\section{Eleni Kolaiti and Nikos Mourtzas}

mortar, was founded on land and today its foundation level is at $0.95 \mathrm{~m}$ bmsl (Figure 13a). In addition, the foundations of an enclosure seawall, also built on land on the SW end of the rocky outcrop, now bounding on the north side the shallow (max depth $1.80 \mathrm{~m}$ ) picturesque fishing harbour formed between it and the modern docks, have been submerged at $1 \mathrm{~m}$ bmsl (Figures 13a, b).
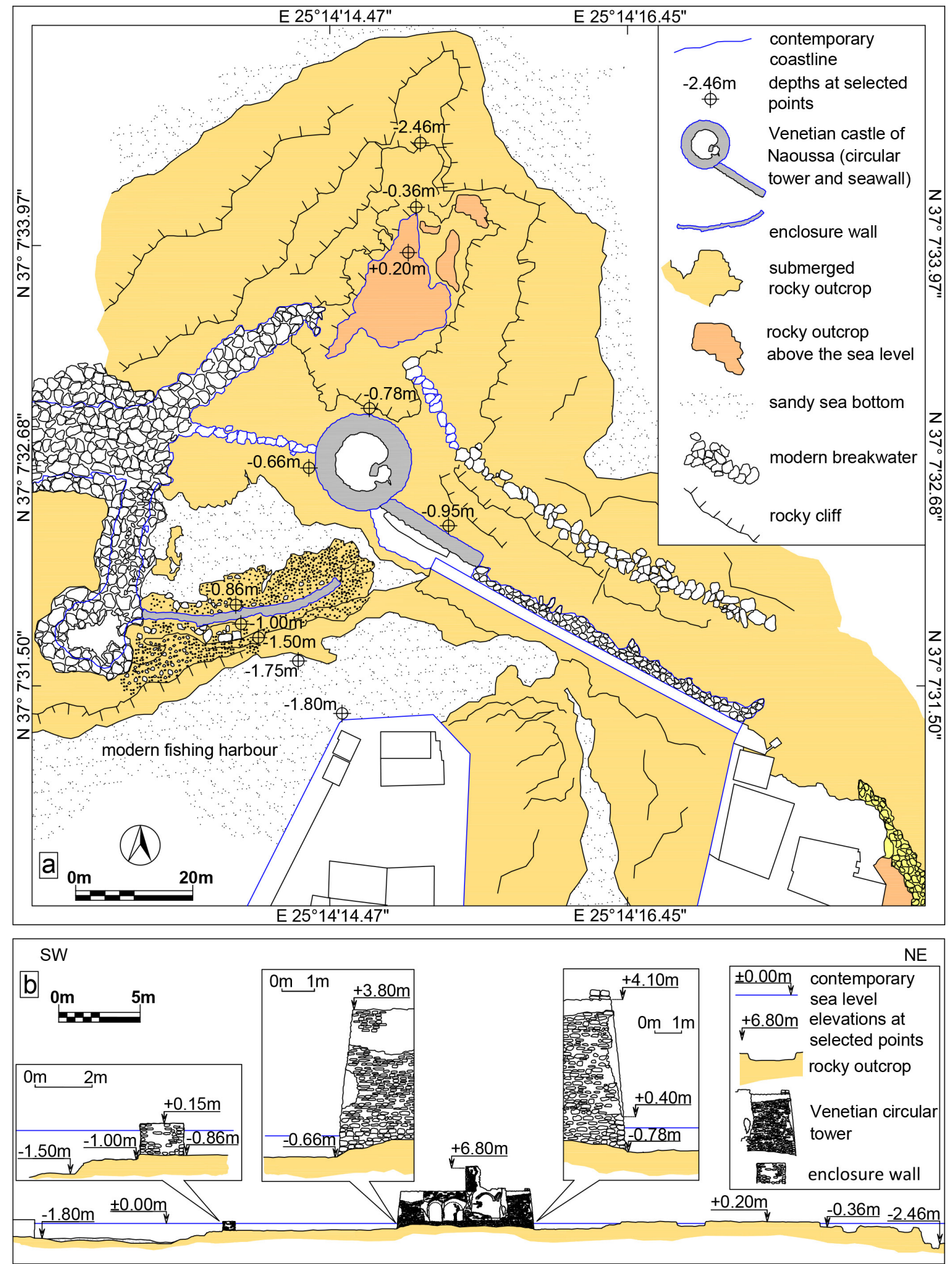

Figure 13. (a) Plan of the Venetian castle of Naoussa. (b) SW-NE cross-section of the castle area. 


\subsubsection{Threshing floor and protective rockfill}

The coastal plain on the NE side of Lageri Bay (Figure 1c) was an area of intense agricultural activity in the recent past, as evidenced by at least five threshing floors preserved to date (Figure 14). According to Vionis [2006], it seems that during the Middle Byzantine period the settled landscape was transferred from the bay of Paroikia to that of Naoussa in the north, whereas small peasant communities made use of the fertile land surrounding rural settlements and the safe anchorage of bays around the island.

The easternmost out of five preserved threshing floors was founded on the surface of a rocky reef, which now forms a small submarine promontory developing in a SW direction. It has a diameter of $8 \mathrm{~m}$, a perimeter wall built of rectangular blocks, hard floor paved with slabs, of which few are currently preserved, and in its centre three large blocks among which a wooden pole may be placed. The preserved parts of the paved floor are submerged at $0.80 \mathrm{~m}$ bmsl and the foundation of the slabs at $1 \mathrm{~m} \mathrm{bmsl}$ (Figure 14). The large amount of ceramic fragments around the submerged threshing floor, some of them glazed, indicate that the area was in use either during the Venetian domination (1207 - 1537) or possibly later during the Ottoman rule (1537-1821).

At the southern end of the lowland, within $13 \mathrm{~m}$ from the shoreline, three more threshing floors were found on land, at an elevation not exceeding $1.50 \mathrm{~m}$. All along the seafront, where the farmhouse and the three threshing floors are located, a protective rockfill has been found about $7 \mathrm{~m}$ offshore (Figure 14). It is $172 \mathrm{~m}$ long and $3 \mathrm{~m}$ to 3.50 $\mathrm{m}$ wide and is made of rubblestones up to $0.40 \mathrm{~m}$ in size. The seaward and landward base of the rockfill is at $0.90 \mathrm{~m}$ to $1 \mathrm{~m}$ bmsl and its top at $0.60 \mathrm{~m}$ to $0.65 \mathrm{~m}$ bmsl.

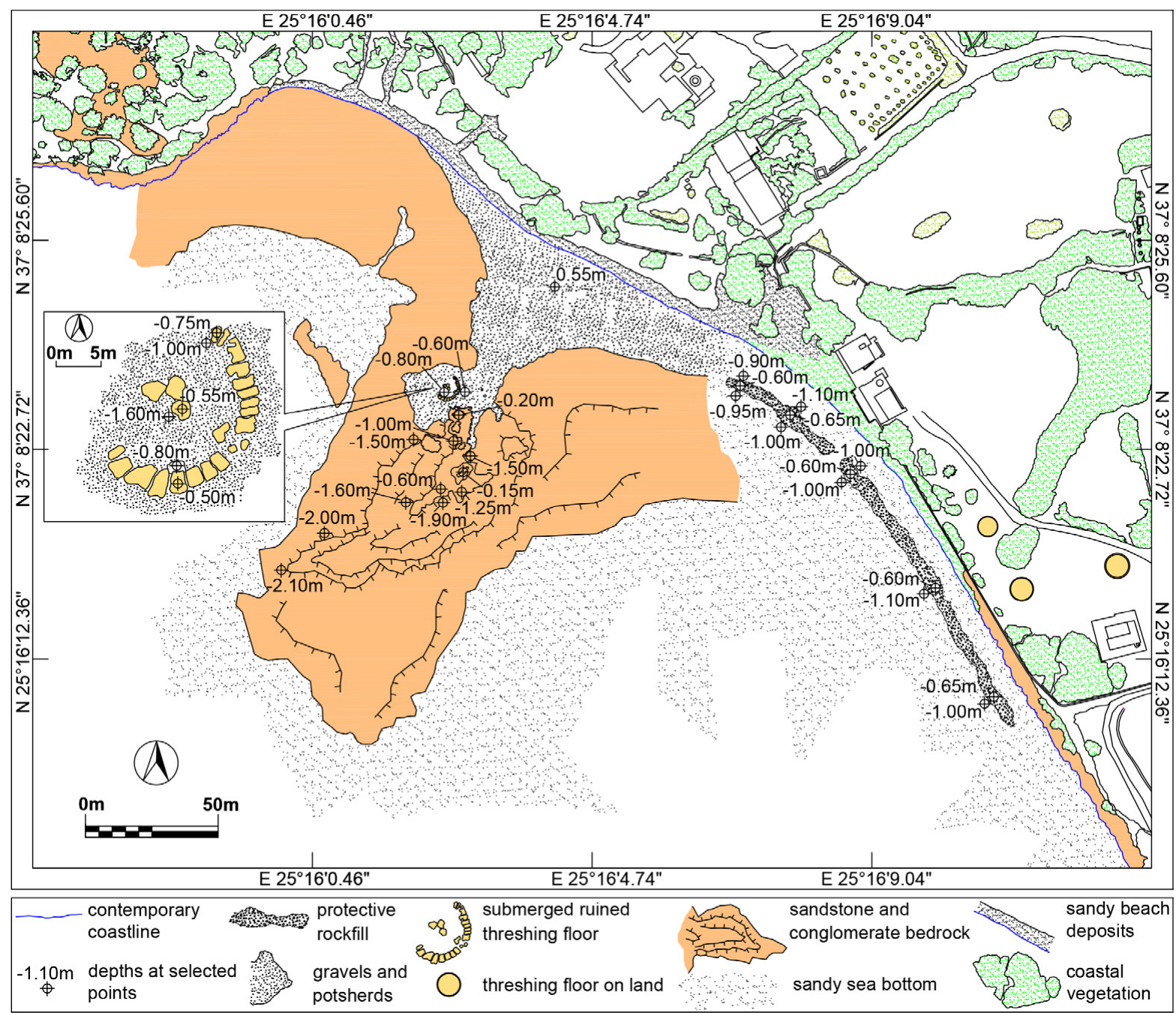

Figure 14. Plan of the Lageri coast. 


\section{Eleni Kolaiti and Nikos Mourtzas}

\section{Discussion}

Marine transgressions that occurred throughout the Late Holocene have radically changed the palaeogeography of the coast of Paros, by submerging below sea level the coastal landscape and the maritime and other coastal constructions from the Late Neolithic to the present.

The deepest sea level stand (I) at $4.90 \pm 0.10 \mathrm{~m}$ bmsl is determined by the deepest beachrock generation (I) in Logaras Bay (Figures 4b, 15a). The dating of this sea level has been indirectly achieved taking into consideration the prerequisites for the Neolithic settlement of Saliagos to flourish between 4300 BC and 3700 BC: the intense farming activity on Saliagos, despite the small size of the islet and its lack of fresh water and arable land and pastures [Morrison, 1968], goes beyond the limits of the present rocky islet and implies a broader terrestrial area associated with it, one which today is inundated by the sea. Given that the morphology of the rocky seabed has not changed since it sunk and the maximum depth between the two islands and at Paros-Antiparos Strait to the south does not exceed $5 \mathrm{~m}$, the use and flourishing of the Saliagos site can be associated with the sea level stand at $4.90 \pm 0.10 \mathrm{~m}$ bmsl found on the coast of Paros (Figure 15a). The contemporary depth (at $5 \mathrm{~m} \mathrm{bmsl}$ ) of the rockfill, probably placed during the same period for defence purposes at the southern edge of the then terrestrial part of Paros-Antiparos Strait, provides further evidence on the dating of the deepest sea level stand (I).
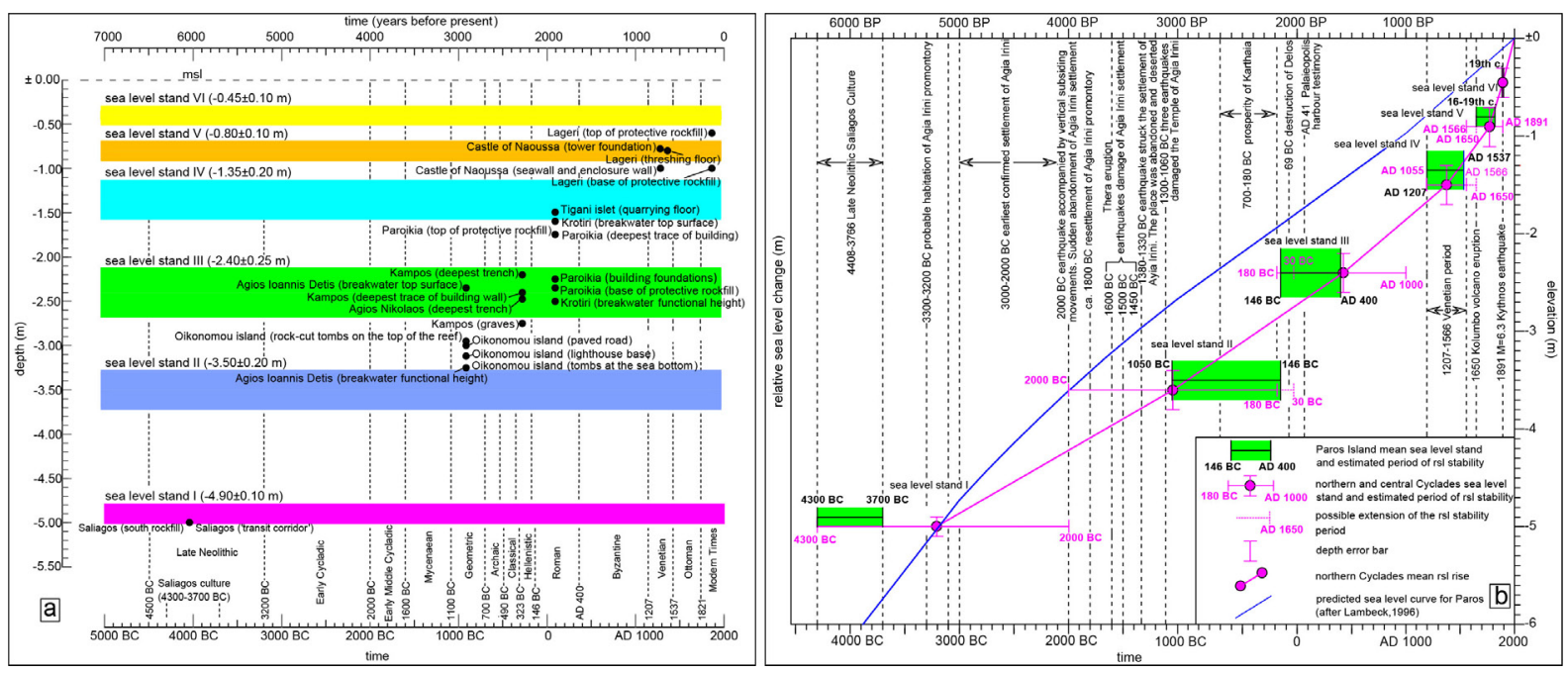

Figure 15. (a) The functional height of the dated archaeological rsl indicators in relation to the six sea level stands determined for Paros Island. (b) The rsl curve for Paros during the last 6,300 years with respect to the rsl curve of the northern and central Cyclades. Important historical and geodynamic events are highlighted. (msl: mean sea level).

The next sea level stand (II) at $3.50 \pm 0.20 \mathrm{~m}$ bmsl (Figures $4 \mathrm{~b}, 15 \mathrm{a}$ ) is determined by the beachrock generation (II) that has been identified in Logaras and Molos Bays and on the Martselo coast. The sea level when the harbour installations and constructions of the Geometric and Archaic periods (1050 - 490 BC) were in use appears to coincide with this sea level stand, which is therefore dated to this historical period. In particular:

- The maximum depth of the top surface of the breakwater at Agios Ioannis Detis, below the Geometric settlement, is between $2.35 \mathrm{~m}$ and $2.60 \mathrm{~m} \mathrm{bmsl}$. Auriemma and Solinas [2009], after studying many archaeological remains from the Tyrrhenian and Adriatic coast, suggested for the Adriatic coast a "functional height" for a breakwater of 0.60-0.70 $\pm 0.23 \mathrm{~m}$ above mean sea level (amsl) during the period that it was in use. Benjamin et al. [2017] set the basis, and subsequently, based on many case studies from the Aegean, Kolaiti [2019] accomplished the protocol for the use of ancient maritime installations as archaeological rsl indicators and suggested that a mean elevation of the top surface of a dock, jetty or breakwater of $0.60 \pm 0.30 \mathrm{~m}$ amsl during the period it was in use could "safely" be adopted. Such an 
assumption, in this case, could refer to a mean sea level of $3.20 \mathrm{~m}$ bmsl or a maximum sea level of 3.50 m bmsl.

- The large piles of stones, interpreted as lighthouses at the NW end of Zoodochos Pigi Bay and probably associated with the Geometric and Archaic habitation of Oikonomou Island [Schilardi, 1973; Kourayos, 2015], were founded on the then rocky outcrop in dry conditions, as evidenced by the carvings - probably graves on the surface of the contemporary reef. The surface of the reef where the piles of stones are laid is today submerged at up to $3.20 \mathrm{~m}$ bmsl, the grave between Oikonomou Island and the Zoodochos Pigi coast is at $3.25 \mathrm{~m} \mathrm{bmsl}$, and the paved road south of the reef at $3 \mathrm{~m}$ bmsl (Figure 15a). The palaeogeographic reconstruction of Oikonomou Island when the sea level was at $3.50 \pm 0.20 \mathrm{~m}$ bmsl is shown in Figure $8 \mathrm{~b}$.

In addition, the interpretation that we have adopted for the rock-cut trenches that were intended for vine cultivation presupposes a difference in elevation of 1-2 $\mathrm{m}$ with reference to the sea level, as is observed in modern coastal vineyards along the coastal zone of the Voutakos area. Given that the last trace of trenches was identified at $2.48 \mathrm{~m}$ bmsl on the Agios Nikolaos coast (Figure 9c) and at $2.20 \mathrm{~m}$ bmsl on the Kampos coast (Figure 9b), and taking into consideration the depths of the building complex and the rock-cut tombs on the Kampos coast at 2.40 $\mathrm{m}$ and $2.75 \mathrm{~m}$ bmsl, respectively (Figure 9b), human activities could have been accomplished there with sea level $3.50 \pm 0.20 \mathrm{~m}$ (sea level stand II) lower than at present. The hypothesis of Evans and Renfrew [1968] and Morrison [1968] that the partially submerged system of trenches on Paros, Antiparos and Revmatonisi was cut in Hellenistic times, which means in the period between 323 and $146 \mathrm{BC}$, but also the widespread Classical/Hellenistic ceramics in the area of Voutakos [Vionis, 2006], allow us to suggest that the sea level stand (II) could have lasted even during the Hellenistic period (Figuure 15a).

The beachrock generation (III) identified on the Martselo coast at $2.55 \pm 0.15 \mathrm{~m}$ bmsl and the deepest marine notch on Gaidouronisi Islet, as well as on the NW coast of Paros at a depth of $2.15 \mathrm{~m}$ to $2.20 \mathrm{~m}$ bmsl, determine a sea level stand (III) at $2.40 \pm 0.25 \mathrm{~m}$ bmsl during the Roman period of Paros (146 BC - 4th c. AD) (Figs. 4b, 15a). From the last visible trace of the foundations of the Roman building complex on the Paroikia coast, found at $1.75 \mathrm{~m}$ bmsl, and by adding at least $0.50 \mathrm{~m}$ for a stone foundation course, given that the foundation was (then) constructed on land, we can infer that the foundation level should be at $2.25 \mathrm{~m}$ bmsl (Figure 10). Also, the piles of stones - either protective rockfills or cairn-like landmarks - constructed along the then shoreline in front of the building, with their base at $2.35 \mathrm{~m} \mathrm{bmsl}$, are linked to the sea level (III) at $2.40 \pm 0.25 \mathrm{~m}$ found on the coast of Paros (Figure 15a).

Evidence is provided for the age of the breakwater on the Krotiri coast, which has not been (archaeologically) dated so far. Taking into account the functional height of a breakwater, as presented above, the contemporary depth of the ancient breakwater at Krotiri (Figure 11) could refer to the sea level stand (III) of $2.40 \pm 0.25 \mathrm{~m}$ bmsl that has been identified as the Roman sea level on the coast of Paros (Figure 15a).

The ancient quarry on Tigani Islet operated right next to the shore so that the extracted blocks could be transported by sea. The age of an ancient quarrying site as well as any rock-cut remains is uncertain and is usually indirectly approached. For a submerged quarryscape, it is assumed a minimum elevation of the original quarrying floor at $0.30 \mathrm{~m}$ above high tide in order for it to be kept dry, which suggests a minimum "functional height" of 0.60 $\mathrm{m}$ with respect to the msl of the period in which it was in use [Auriemma and Solinas, 2009; Scicchitano et al., 2018; Kolaiti, 2019]. Since the deepest trace of exploitation was found at $1.50 \mathrm{~m} \mathrm{bmsl}$ (Figure 12), the period of use of the quarrying site probably falls within the Roman sea level at $2.40 \pm 0.25 \mathrm{~m}$ bmsl (Figure 15a).

The next sea level stand (IV) is determined by the beachrock generation (IV) found in Logaras and Molos Bays and on the Martselo coast at $1.35 \pm 0.20 \mathrm{~m}$ bmsl. The castle of Naoussa, founded on the flattened surface of a rocky outcrop, is today submerged at $0.78 \mathrm{~m} \mathrm{bmsl}$, while the foundations of the enclosure wall and the seawall are at $1 \mathrm{~m}$ bmsl (Figure 13), thus dating the sea level stand (IV) to the Venetian period. The threshing floor on the Lageri coast, today at $0.80 \mathrm{~m}$ bmsl, which was probably in operation during the Venetian occupation of Paros, could also be linked to the Venetian sea level stand (IV) (Figure 15a).

The following sea level stand $(\mathrm{V})$ is determined by the youngest beachrock generation $(\mathrm{V})$ found on Pounda coast at $0.80 \pm 0.10 \mathrm{~m}$ bmsl (Figures $4 \mathrm{~b}, 15 \mathrm{a}$ ). The rockfill on the Lageri coast was constructed along the then coastline after the flooding of the threshing floor to protect the building and the three threshing floors against sea erosion (Figure 14). The measured depths of the top and base of the rockfill at $0.60 \mathrm{~m}$ and $1 \mathrm{~m} \mathrm{bmsl}$, respectively, indicate that it was placed there when the sea level was between those depths after the Venetian period and during the Ottoman rule of the island (1537-1821). Consequently, the rockfill is related to the sea level stand (V) (Figure 15a). 


\section{Eleni Kolaiti and Nikos Mourtzas}

The most recent sea level stand (VI), determined by the shallowest marine notch on Gaidouronisi Islet and at Aspra Chomata at $0.45 \pm 0.10 \mathrm{~m}$ (Figures $4 \mathrm{~b}, 15 \mathrm{a}$ ), is dated to the recent change in the sea level from the late $19^{\text {th }}$ c. onward. Although we have reservations about the accuracy of the depth (6 ft) given in Roux's map [1804], a comparison with the current average depth of the Roman breakwater on Krotiri coast roughly suggests a rsl rise of $0.45 \mathrm{~m}$ during the last 215 years, which matches the most recent sea level stand (VI).

Conflicting views on the rsl changes in the Cyclades have been expressed in a series of papers since 2012. Evelpidou et al. [2012b] suggested that the rsl reached $\sim 2.00 \mathrm{~m} \pm 0.50$ at about $\sim 4000 \mathrm{BP}$ in the adjacent western Naxos [Karkani et al., 2019]. In a subsequent publication, Evelpidou et al. [2014] stated that the sea level was at $2.90 \mathrm{~m}$ before the period $3350-4200 \mathrm{yr} \mathrm{BP},-2.30 \mathrm{~m}$ around $3100 \mathrm{yr} \mathrm{BP}$, above $-1.78 \pm 0.50 \mathrm{~m}$ around $1752 \pm 40 \mathrm{yr} \mathrm{BP}$, at $-1.00 \pm 0.10 \mathrm{~m}$ around $941 \pm 40 \mathrm{yr} \mathrm{BP},-0.75 \pm 0.10 \mathrm{~m}$ about $900 \mathrm{BP}$ and $-0.35 \pm 0.05 \mathrm{~m}$ around $232 \pm 35 \mathrm{yr} \mathrm{BP}$. Karkani et al. [2017] determined three sea level stands along the coast of Paros: the shallowest between $-0.80 \pm 0.20$ and $-1.80 \pm 0.20 \mathrm{~m}$ yielded an age between $1500 \pm 70 \mathrm{yr} \mathrm{BP}$ and $1000 \pm 160 \mathrm{yr} \mathrm{BP}$ and the deepest sea level at -5.60 $\pm 0.50 \mathrm{~m}$ between $1720 \pm 80 \mathrm{yr}$ BP and $1390 \pm 190 \mathrm{yr}$ BP, although the authors admitted that the latter age "does not seem credible for such a deep shoreline". Subsequently, Karkani et al. [2018] suggested for Paros that between 3100 and 3300 yr BP the sea level was between $-1.50 \mathrm{~m}$ and $-2.50 \mathrm{~m}$. Recently, however, Karkani et al. [2019] rejected the previous ages and stated that the rsl had risen by $\sim 2 \mathrm{~m}$ over the previous 2000 years and by at least $\sim 3.90 \mathrm{~m}$ since $\sim 4500 \mathrm{yr}$ BP. Apart from the difficulty in following such contradictory views, the reader would have the impression that the coastal human activities on Paros from the Late Neolithic to Modern Times had taken place underwater. For example, if the sea level had been at $-2 \mathrm{~m}$ to $-2.50 \mathrm{~m}$ between $3300 \mathrm{yr}$ BP [Karkani et al., 2018] and $2000 \mathrm{yr}$ BP [Karkani et al., 2019], the graves found in both the north and south bays of Oikonomou Island would have been constructed under the sea, whereas the rock-cut trenches on the coast of Voutakos and Kampos, would have been mostly below sea level. If the sea level had been between $-0.75 \mathrm{~m}$ and $-1 \mathrm{~m}$ around $1000 \mathrm{AD}$ [Evelpidou et al., 2014], the flattened surface and the foundation of the Naoussa Castle would have been on an inundated area and the threshing would have been carried out underwater on the Lageri coast.

In a recent publication, Bechor et al. [2019] suggested for the entire Cyclades plateau a Medieval sea level at $1.20 \pm 0.26 \mathrm{~m}$ in $1300 \pm 30$ climbing to $-0.70 \pm 0.26 \mathrm{~m}$ in $1500 \pm 30$, based only on two measurements from the castle of Naoussa (Paros). However, they did not take into consideration that (a) both constructions were founded on a rocky outcrop with uneven elevations and with a sea level lower than its surface (Figure 13), and (b) the seawall and the enclosure wall, which were built in different periods $\left(13^{\text {th }}-14^{\text {th }} \mathrm{c}\right.$. and $15^{\text {th }} \mathrm{c}$., respectively), are today at the same depth $(-0.95 \mathrm{~m}$ and $-1 \mathrm{~m}$, respectively).

\section{Late Holocene rsl changes in the northern and central Cyclades}

Geomorphological, archaeological and historical evidence of past sea levels on the islands of Keos, Andros, Kythnos, Syros and Paros, and the insular group of Mykonos, Rhenia and Delos, enabled us to determine six distinct sea level stands in the northern and central Cyclades and draw the rsl curve for the last 6,300 years [Desruelles et al., 2009; Mourtzas and Kolaiti, 2016; Mourtzas, 2018] (Figure 15b).

The Late Holocene history of the rsl changes begins with the sea level at $5.00 \pm 0.10 \mathrm{~m}$ bmsl. Little evidence of this earliest sea level is provided and is mainly limited to the deepest beachrock generation in the bays of Poles (SE Keos, $5.15 \pm 0.20 \mathrm{~m} \mathrm{bmsl}$ ), Kavia (Koundouros, SW Keos, $4.50 \pm 0.20 \mathrm{~m} \mathrm{bmsl}$ ), Mesa Steno (S Andros, $4.97 \mathrm{~m}$ bmsl), Kalafati (S Mykonos, $4.80 \mathrm{~m}$ bmsl) and Paros (Logaras, $4.90 \pm 0.10 \mathrm{~m} \mathrm{bmsl}$ ) [Mourtzas, 2010, 2018; this study]. This sea level appears to be associated with a time interval between the Late Neolithic and the end of the Early Bronze Age, from 4300 BC to 2000 BC. The earliest traces of habitation in the bays of Mikres and Megales Poles (SE Keos) found in the depth of $3.10 \mathrm{~m}$ to $4.12 \mathrm{~m}$ bmsl between the two deeper beachrock generations [Mourtzas, 2010] and the sudden abandonment around $2000 \mathrm{BC}$ - with no trace of violence - of the Early Bronze Age settlement of Agia Irini (NW Keos) (3300 BC to $2000 \mathrm{BC}$ ), are most likely related to this sea level stand and its abrupt change to the following stand [Mourtzas and Kolaiti, 2016]. The flourishing of the Neolithic settlement of Saliagos in the ParosAntiparos Strait ( 4300 to $3700 \mathrm{BC}$ ) is related to the sea level stand at $4.90 \pm 0.10 \mathrm{~m}$ bmsl, which enabled communication by land with the surrounding area [Morrison 1968; this study] (Figure 15b).

The next sea level stand is detected throughout the area of the northern and central Cyclades at $3.60 \pm 0.20$ $\mathrm{m}$ bmsl. Many beachrock formations have been found on SE Keos (Poles Bay, $3.80 \pm 0.45 \mathrm{~m}$ bmsl) and SW Keos 
(Kavia and Ligia Bays, $3.35 \mathrm{~m}$ to $3.45 \mathrm{~m}$ bmsl), in the insular group of Mykonos (Agios Ioannis, Paradise, Agrari, Agia Anna, Kalafati, Panormos, Agios Sostis, $3.60 \mathrm{~m}$ to $3.90 \mathrm{~m}$ bmsl), Rhenia (Kormou Ammos, Steni and Lazaret, $3.60 \mathrm{~m}$ to $4 \mathrm{~m} \mathrm{bmsl}$ ) and Delos (Fourni, $3.60 \mathrm{~m} \mathrm{bmsl}$ ), and on Paros (Logaras and Molos Bays and the Martselo coast, $3.30 \mathrm{~m}$ to $3.70 \mathrm{~m}$ bmsl) [Mourtzas and Kolaiti, 1998; Desruelles et al., 2009; Mourtzas, 2007, 2010, 2012, 2018; this study]. This sea level stand is dated to between the end of the Early Bronze Age ( $2000 \mathrm{BC}$ ) and 180 $\mathrm{BC}$. The dating was indirectly made, by comparison with characteristic elevations from the prehistoric settlement of Agia Irini on NW Keos (2000 -1300 BC) (Mourtzas and Kolaiti, 2016), the harbour structure in Otzias Bay (4 $4^{\text {th }}$ c. BC) on N Keos and the extensive harbour installations of ancient Karthaia on SE Keos ( $8^{\text {th }} \mathrm{c}$. BC to the end of prosperity around 180 BC) [Mourtzas and Kolaiti, 1998; Mourtzas, 2010], the coastal fortification of Classical Palaeopolis ( $5^{\text {th }}$ to $3^{\text {rd }}$ c. BC) in W Andros [Mourtzas, 2007, 2018], the Classical archaeological layers at $3.65 \mathrm{~m}$ to $3.85 \mathrm{~m}$ bmsl in the ancient harbour of Vryokastro in Mandraki Bay in W Kythnos (Kythnos Excavation Project 19902014), the Geometric breakwater of Agios Ioannis Detis (N Paros), the submerged Geometric or Archaic lighthouses, tombs and paved road in Zoodochos Pigi Bay (N Paros), and the rock-cut trenches found all around the coast of Paros (this study). According to Mourtzas [2012], this sea level stand probably lasted until 30 BC (Figure 15b).

The sea level stand at $2.40 \pm 0.20 \mathrm{~m}$ bmsl was evidenced by the marine notches in three locations along the eastern coast of Paros and on the western cliff of Gaidouronisi Islet ( $2.10 \mathrm{~m}$ to $2.20 \mathrm{~m} \mathrm{bmsl}$ ) (this study) and the beachrock formations on Keos (Agios Nikolaos Gulf, Orkos and Poles Bays, the coves south of Koundouros, $2.20 \mathrm{~m}$ to $2.60 \mathrm{~m} \mathrm{bmsl}$ ), SE Andros (Korthi and Exo Steno Gulfs, $2.30 \mathrm{~m} \mathrm{bmsl}$ ), NW Delos (seafront of ancient Delos and Fourni, $2.20 \mathrm{~m}$ to $2.60 \mathrm{~m} \mathrm{bmsl}$ ), SW Mykonos (Mykonos new port, Agios Ioannis, Paraga, Paradise, Agia Anna, Kalafati, Ftelia, Panormos, Agios Sostis, $2.15 \mathrm{~m}$ to $2.50 \mathrm{~m} \mathrm{bmsl}$ ), E Rhenia (Lazaret, $2.20 \mathrm{~m} \mathrm{bmsl}$ ) and W Paros (Martselo, $2.55 \pm 0.15 \mathrm{~m}$ bmsl) [Mourtzas and Kolaiti, 1998; Desruelles et al., 2009; Mourtzas, 2010, 2012, 2018; this study]. This sea level stand has been established as being sometime between $30 \mathrm{BC}$ (ancient Delos) and 41 $\mathrm{AD}$ (Palaeopolis, W Andros) and has been dated by the functional height of the Roman shipshed in Poises Bay (W Keos), the submerged Roman structure in Exo Steno Gulf (S Andros), the Roman harbour of ancient Palaeopolis (W Andros) [Mourtzas and Kolaiti, 1998; Mourtzas, 2010, 2012, 2018], the submerged Roman harbour installations in Mandraki Bay (W Kythnos, $2.45 \mathrm{~m}$ bmsl) (Kythnos Excavation Project 1990-2014), the Roman building complex, the protective rockfill and the rubble mound breakwater in Paroikia Gulf (W Paros), and the submerged ancient quarry on Tigani Islet (SW Paros) (this study). Based on radiocarbon ages that provide an age of 960 BP (Desruelles et al., 2009), this sea level stand could be prolonged until about 1000 AD (Figure 15b).

The next sea level stand at $1.50 \pm 0.20 \mathrm{~m}$ bmsl is dated to the period of the Venetian occupation of the Cyclades (1207-1566 AD). It is evidenced by the marine notches in Poles Bay (SE Keos, $1.30 \pm 0.05 \mathrm{~m} \mathrm{bmsl}$ ) and Plaka Bay (W Andros, $1.35 \pm 0.05 \mathrm{~m} \mathrm{bmsl}$ ) [Mourtzas and Kolaiti, 1998; Mourtzas, 2010] and the beachrocks throughout the coast of Keos (bays of Spathi, Agia Irini, Orkos, Kavia, Ligia and Kampi, $1.10 \mathrm{~m}$ to $1.65 \mathrm{~m} \mathrm{bmsl}$ ), Andros (Vlychadia, Agios Petros, Anerousa, Palaeopolis, Gyalia, Kremmydes, Mesa Steno bays, $1.30 \mathrm{~m}$ to $1.65 \mathrm{~m}$ bmsl), Mykonos (Agios Ioannis, Platis Gialos, Paraga, Super Paradise, Agios Sostis, $1.15 \mathrm{~m}$ to $1.75 \mathrm{~m}$ bmsl), Delos (Fourni, $1.20 \mathrm{~m} \mathrm{bmsl}$ ), Rhenia (Kormou Ammos and Steni coast, $1.50 \mathrm{~m}$ to $1.70 \mathrm{~m} \mathrm{bmsl}$ ) and Paros (Logaras and Molos Bays, the Martselo coast, $1.20 \mathrm{~m}$ to $1.55 \mathrm{~m}$ bmsl). The dating was attained by comparison with the functional height of a seawall for coastal defense and a shipshed of the Venetian period (AD 1207-1566) on the coast of Nimporio (Chora, E Andros) and the Venetian castles of Mykonos (Chora) and Paros (Naoussa) (this study). This sea level stand could extend to the period between 1649 and 1735, which witnessed a series of strong seismic events, including the explosion of the Kolumbo submarine volcano (NE Santorini) in 1650 (Figure 15b).

The sea level stand at $0.90 \pm 0.20 \mathrm{~m}$ bmsl was evidenced by the beachrock generations found on Keos $(0.65$ $\mathrm{m}$ to $0.90 \mathrm{~m} \mathrm{bmsl})$, Syros $(0.95 \pm 0.05 \mathrm{~m} \mathrm{bmsl})$, Andros ( $0.58 \mathrm{~m}$ to $1.05 \mathrm{~m} \mathrm{bmsl})$, Delos $(0.90 \mathrm{~m} \mathrm{bmsl})$ and Paros (Pounda coast at $0.80 \pm 0.10 \mathrm{~m} \mathrm{bmsl}$ ) [Mourtzas and Kolaiti, 1998; Mourtzas, 2010, 2012, 2018]. There is a little evidence for the dating of this sea level, only that arising from the rockfill on the Lageri coast (N Paros), which dates it to after the Venetian period and during the Ottoman rule of Cyclades. The change to the next sea level stand could be linked to the strong seismic sequence that struck Kythnos Island between 29.4.1891 and 11.5.1891 (Figure 15b).

Finally, the latest sea level stand in the area of the northern Cyclades at $-0.45 \pm 0.15 \mathrm{~m}$ was deduced from the depth of the well-formed marine notches in Poles Bay (SE Keos, $0.50 \pm 0.05 \mathrm{~m} \mathrm{bmsl}$ ), along the eastern coast of Paros Island and on the western cliff of Gaidouronisi Islet (0.38 m to $0.45 \mathrm{~m} \mathrm{bmsl}$ ) [Mourtzas, 2010, 2012, 2018; 


\section{Eleni Kolaiti and Nikos Mourtzas}

present study]. This deduction is supported by the most recent beachrock generations found on W Andros (Agios Petros and Pissolimnionas, $0.60 \pm 0.05 \mathrm{~m}$ bmsl) and NW Keos (Ayia Irini, $0.65 \mathrm{~m} \mathrm{bmsl}$ ) [Mourtzas, 2010, 2012, 2018; Mourtzas and Kolaiti, 2016; present study]. It can be attributed to the recent change in the sea level after the late $19^{\text {th }} \mathrm{c}$. onward, as evidenced by the submerged foundations and part of the superstructure of the coastal buildings at "Little Venice" in Chora (Mykonos) at 0.50 bmsl (Figure 15b).

\section{The rsl curve for the northern and central Cyclades}

The rsl curve for the northern and central Cyclades during the last 6,300 years is shown in Figure 15b. The diagram collates the six successive periods of rsl stability for Paros and the relevant periods for the northern and central Cyclades, their probable duration and the intervening periods of rsl change. Milestones such as important events from the prehistory and history of the northern Cyclades (e.g. period of prosperity or abrupt abandonment of a settlement), and significant geodynamic events, such as volcanic eruptions and strong earthquakes, that play a key role in dating the former sea levels and their changes, are also indicated. The mean rsl curve represents the mean rate of the rsl change during the Late Holocene for the northern and central Cyclades (Figure 15b).

The mean rate of rsl change, as deduced from the rsl curve for Paros and the northern and central Cyclades (Figure 15b), increases from $0.63 \mathrm{~mm} / \mathrm{yr}$ (3200-1050 BC) to $0.78 \mathrm{~mm} / \mathrm{yr}$ (1050 BC-430 AD), $1.09 \mathrm{~mm} / \mathrm{yr}$ (430-1390 $\mathrm{AD}), 1.54 \mathrm{~mm} / \mathrm{yr}(1390-1780)$ and $2.35 \mathrm{~mm} / \mathrm{yr}$ (1780 to date). It is noticeable that the rsl change rates are accelerating and this is mainly attributed to glacio-istostacy, since the tectonic component is being redused over time. The mean inferred rsl change rate of $0.96 \mathrm{~mm} / \mathrm{yr}$ during the Late Holocene for the northern and central Cyclades is significantly lower than that suggested by Lykousis [2009] at $1.38 \mathrm{~mm} / \mathrm{yr}$ for the eastern Cyclades plateau for the time span between $\sim 425 \mathrm{ka}$ BP and $13 \mathrm{ka}$ BP.

The separation between tectonics and glacio-hydro-isostatic signals from the observed rsl curves allow us to define the amount of tectonic contribution to the rsl change, and obtain the vertical tectonic rates [e.g. Lambeck, 1995; Lambeck et al., 2004; Antonioli et al., 2011; Anzidei et al., 2011, 2013, 2014]. Lambeck's model [1996] predicts a rising sea level for the Cyclades since 6,000 yr BP, which appears to be consistent with the observed rsl stand (I) deduced from this study (Figure 15b). However, for the following observed rsl stands, a strong tectonic component with respect to Lambeck's (1996) prediction is extracted, ranging from $0.45 \mathrm{~m}$ to $1.06 \mathrm{~m}$ [sea level stand (II): 0.95 m, (III): $1.06 \mathrm{~m},(\mathrm{IV}): 0.84 \mathrm{~m},(\mathrm{~V}): 0.62 \mathrm{~m},(\mathrm{VI}): 0.45 \mathrm{~m}$ ]. The tectonic component that results from the model of Roy and Peltier [2018] since $2 \mathrm{ka}$ BP for the Cyclades is higher by $1 \mathrm{~m}$ than that of Lambeck [1996] for the same time span. Excessively higher values than those of Lambeck [1996] - by $4 \mathrm{~m}$ for 5,000 yr BP to $1.50 \mathrm{~m}$ for 3,000 yr BP - are suggested by Stocchi et al. [2010], by comparing two different ice chronologies: ANU [Lambeck et al., 2004] and ICE-5G [Peltier, 2004]. Although the seismic quiescence in the Cyclades archipelago, amid the intense seismic activity of the Hellenic area [Jackson and McKenzie, 1984; Taymaz et al., 1991], projects the image of a neotectonically inactive portion of the crust during the Late Holocene, the contribution of the tectonic component to the rsl changes plays a decisive role in the post-glacial sea-level rise.

The main differentiation from all of the suggested glacio-hydro-isostatic models [Lambeck,1996; Lambeck and Purcell, 2005; Peltier et al., 2015; Roy and Peltier, 2018; Stocchi et al., 2010] consists in the long periods of rsl stability, which signify long periods of tectonic quiescence and abrupt changes in the sea level, which are obviously associated with strong deformation events. The "aseismically deformed" area of the northern and central Cyclades is probably the result of the existence of a very closely spaced geometric fracture framework within the metamorphic rocks, preventing strain accumulation. Thus, energy release manifests itself in continuous deformations creeping along the fracture planes [Papanikolaou et al., 1981].

\section{Conclusions}

In the present study, we attempted to track the rate, timing and location of the successive marine transgressions along the coast of Paros island during the Late Holocene. Geomorphological and archaeological rsl indicators surveyed throughout the coastline of Paros contributed to the estimation of the rsl rise, the plotting of the rsl curve for Paros and the definition of the tectonic contribution to the rsl change, in an apparently stable, aseismic region of the crust of the 
Aegean microplate. The correlation between the sea level stands determined for Paros and those for the northern and central Cyclades revealed a uniform tectonic behaviour of the entire northern and central part of the Cyclades plateau.

The application of a geoarchaeological method of approaching the geomorphological and archaeological rsl markers, including systematic observation, multiple and accurate measurements of depths/elevations and data correction for tide and pressure effects, and also the deep understanding of the functionality of the ancient maritime and coastal installations with respect to a past sea level, can enable us to determine and date the former sea level stands, estimate the trends, magnitude and frequency of the vertical tectonic movements, and validate the proposed geophysical models with greater accuracy.

Acknowledgments. The study of the sea level changes in Cyclades began within the research project Neotectonic deformations of the Aegean islands during the Upper Holocene and their impact on archaeological sites and monuments, directed by Professor Paul Marinos, National Technical University of Athens (Emeritus), and funded by the General Secretary of Research and Technology of the Hellenic Ministry of Industry (1991-1993). We would like to thank the KÁ Ephorate of Prehistoric and Classical Antiquities of the Cyclades (Greece), and especially the former Director, Fotini Zafeiropoulou, for giving us the permission and her support during the surveys and the interpretation of field data. Thanks are also due to Professor Stefano Furlani, University of Trieste, responsible for the GEOSWIM - Paros 2017 project for sharing data on marine notches and to Dr. Marco Anzidei, INGV (Rome), for sharing data on the quarrying site on Tigani Islet. Finally, we would like to thank Mr. Stephen Taylor, Consultant at Cambridge Assessment English, not only for editing the English text but also for his insightful comments.

\section{References}

Amouretti, M.-C. (1988). La viticulture antique: contraintes et choix techniques, REA, T. XC (1-2), 5-17.

Amouretti, M.-C. (1992). Oleiculture et viticulture dans la Grece antique, in Agriculture in Ancient Greece B. Wells (Editor), Proceedings of the $7^{\text {th }}$ International Symposium at the Swedish Institute at Athens, 16-17 May 1990 (Stockholm, 1992), 77-86.

Antonioli, F., S. Faivre, L. Ferranti and C. Monaco (2011). Tectonic contribution to relative sea level change, Quat. Int., 232 (1-2), 1-4, doi.org/10.1016/j.quaint.2010.10.003.

Antonioli, F., V. Lo Presti, A. Rovere, L. Ferranti, M. Anzidei, S. Furlani, G. Mastronuzzi, E. P. Orru, G. Scicchitano, G. Sannino, R. C. Spampinato, R. Pagliarulo, G. Deiana, E. de Sabata, P. Sanso, M. Vacchi and A. Vecchio (2015). Tidal notches in Mediterranean Sea: a comprehensive analysis, Quat. Sci. Rev., 119, 1-19.

Antonioli, F., L. Ferranti, P. Stocchi, G. Deiana, V. Lo Presti, S. Furlani, C. Marino, P. Orru, G. Scicchitano, E. Trainito, M. Anzidei, M. Bonamini, P. Sansò and G. Mastronuzzi (2018). Morphometry and elevation of the last interglacial tidal notches in tectonically stable coasts of the Mediterranean Sea, Earth-Sci. Rev., 185, 600-623.

Anzidei, M., F. Antonioli, A. Benini, K. Lambeck, D. Sivan, E. Serpelloni and P. Stocchi (2011). Sea level change and vertical land movements since the last two millennia along the coasts of southwestern Turkey and Israel, Quat. Int., 232, 13-20.

Anzidei, M., F. Antonioli, A. Benini, A. Gervasi and I. Guerra (2013). Evidence of vertical tectonic uplift at Briatico (Calabria, Italy) inferred from Roman age maritime archaeological indicators, Quat. Int., 288, 158-167.

Anzidei M., K. Lambeck, F. Antonioli, S. Furlani, G. Mastronuzzi, E. Serpelloni and G. Vannucci (2014). Coastal structure, sea-level changes and vertical motion of the land in the Mediterranean, in Sedimentary Coastal Zones from High to Low Latitudes: Similarities and Differences I. P. Martini and H. R. Wanless (Editors), Geological Society, London, Special Publications, 388.

Auffray, D. (2002). Recherches sur les Entailles Creusees dans le roc sur les iles de Paros, Antiparos et Remmatonisi, in TROPIS VII, Hellenic Institute for the Preservation of Nautical Tradition H. Tzalas (Editor), Proc. of the $7^{\text {th }}$ International Symposium on Ship Construction in Antiquity, Pylos 1999, vol. I, 29-41.

Auriemma, R. and E. Solinas (2009). Archaeological remains as sea level change markers: A review, Quat. Int., 206, 134-146.

Avcioğlu, M., E. Yiğitbaş and A.E. Erginal, A.E. (2016). Beachrock formation on the coast of Gökçeada Island and its relation to the active tectonics of the region, northern Aegean Sea, Turkey, Quat. Int., 401, 141-152. 


\section{Eleni Kolaiti and Nikos Mourtzas}

Baika, K. (2008). Archaeological indicators of relative sea-level changes in the Attico-Cycladic massif: preliminary results, Bull. Geol. Soc. Greece, XLII/II, 33-48.

Bargnesi, E.A., D.F. Stockli, N. Mancktelow and K. Soukis (2013). Miocene core complex development and coeval supradetachment basin evolution of Paros, Greece: In-sights from (U-Th)/He thermochronometry, Tectonophysics, 595-596, 165-182, doi:10.1016/j.tecto.2012.07.015.

Bechor, B., T. Theodoulou, G. Spada, S. Dean and D. Sivan (2019). Medieval relative low sea-level indications from the Peloponnese and the Aegean Sea, Quat. Int., https://doi.org/10.1016/j.quaint.2019.11.026.

Benjamin, J., A. Rovere, A. Fontana, S. Furlani, M. Vacchi, R. Inglis, E. Galili, F. Antonioli, D. Sivan, S. Miko, N. Mourtzas, I. Felja, M. Meredith-Williams, B. Goodman-Tchernov, E. Kolaiti, M. Anzidei and R. Gehrels (2017). Late Quaternary sea-level change and early human societies in the central and eastern Mediterranean Basin: an interdisciplinary review, Quat. Int., 449, 29-57.

Bernier, P. and R. Dalongeville (1996). Mediterranean coastal changes recorded in beach-rock cementation, Zeit. Geomorphol. NF, Suppl.-Bd, 102, 185-198.

Bernier, P., B. J. Guidi and E. M. Bottcher (1997). Coastal progradation and very early diagenesis of ultramafic sands as a result of rubble discharge from asbestos excavations (northern Corsica, western Mediterranean), Marine Geol., 144, 163-175.

Berranger-Auserve, D. (1992). Recherches sur l'histoire et la prosopographie de Paros à l'époque archaïque, Presses universitaires Blaise Pascal, Clermont-Ferrand.

Bohnhoff, M., M. Rische, T. Meier, D. Becker, G. Stavrakakis and H. -P. Harjes (2006). Microseismic activity in the Hellenic Volcanic Arc, Greece, with emphasis on the seismotectonic setting in the Santorini-Amorgos zone, Tectonophysics, 423, 17-33.

Brichau, S., U. Ring, R. A. Ketcham, A. Carter, D. Stockli and M. Brunel (2006). Constraining the long-term evolution of the slip rate for a major extensional fault system in the central Aegean, Greece, using thermochronology, Earth Planet. Sci. Lett., 241, 293-306.

Brun, J.-P. (2003). Le vin et l'huile dans la Méditerranée antique. Viticulture, oléiculture et procédés de transformation, Ed. Errance, coll. des Hespérides, Paris.

Buondelmonti, C. (1420). Description des îles de l'Archipel, Partie 1, version grecque par un anonyme, publiée d'après le manuscrit du Sérail, avec une traduction française et un commentaire par Émile Legrand, Paris: E. Leroux, 1897, https://catalogue.bnf.fr/ark:/12148/cb30176538h.

Carobene, L. (1972). Osservazioni sui solchi di battente attuali ed antichi nel Golfo di Orosei in Sardegna, Bollettino della Societa Geologica, 91, 583-601.

Carobene, L. (2015). Marine Notches and Sea-Cave Bioerosional Grooves in Microtidal Areas: Examples from the Tyrrhenian and Ligurian Coasts-Italy, J. Coastal Res., 31 (3), 536-556.

Cazenave, A., H. -B. Habib-Boubacar Dieng, B. Meyssignac, K. Von Schuckmann, B. Decharme and E. Berthier (2014). The rate of sea-level rise, Nature Climate Change, 4, 358-361, doi:10.1038/nclimate2159.

Christopoulou, D. (1984). The Castelli in Naussa of Paros, Restoration- Conservation-Protection of monuments and ensembles, Technical Periodical Edition of the Ministry of Culture and Sciences, A, 201-224.

Church, J.A., N. J. White, L. F. Konikow, C. M. Domingues, G. Cogley, E. Rignot, J. M. Gregory, M. R. Van den Broeke, A. J. Monaghan and I. Velicogna (2011). Revisiting the Earth's sea-level and energy budgets from 1961 to 2008, Geophys. Res. Lett., 38, L18601, doi:10.1029/2011GL048794.

Coastal-terroirs. EDOAO, National Interprofessional Organization of Vine and Wine, https://winesofgreece.org/articles/coastal-terroirs/.

Dermitzakis, M. and D. Papanikolaou (1980). The molasse of Paros Island, Aegean Sea, Annalen des Naturhistorischen Museums Wien, 83, 59-71.

Desruelles, S., E. Fouache, A. Ciner, R. Dalongeville, K. Pavlopoulos, E. Kosun, Y. Coquinot and J. -L. Potdevin (2009). Beachrocks and sea level changes since Middle Holocene: comparison between the insular group of Mykonos - Delos - Rhenia (Cyclades Greece) and the southern coast of Turkey, Glob. Planet. Chang., 66, 19-33.

Draganits, E. (2009). The Archaic Sanctuary on Despotiko island (Cyclades): Geological outline and lithological characterization of the building stones with their possible prpovenance, Austrian J. Earth Sci., 102, 91-101.

Engdahl, E., R. Van der Hilst and R. Buland (1998). Global telesismic earthquake relocation with improved travel times and procedures for depth determination, Bull. Seismol. Soc. Am., 88, 722-743.

Erginal, A.E. and B. Öztürk (2012). Formation environment of the Kumlimani beachrock (Gelibolu Peninsula), 
Turkish Geographical Review, 57, 87-93.

Evans, D. J. and C. Renfrew (1968). Excavations at Saliagos near Antiparos, The British School of Archaeology of Athens, Thames and Hudson.

Evelpidou, N., D. Melini, P. Pirazzoli and A. Vassilopoulos (2012a). Evidence of a recent rapid subsidence in the S-E Cyclades (Greece): an effect of the 1956 Amorgos earthquake?, Cont. Shelf Res., 39-40, 27-40.

Evelpidou, N., K. Pavlopoulos, A., Vassilopoulos, M. Triantafyllou, K. Vouvalidis and G. Syrides (2012b). Holocene palaeogeographical reconstruction of the western part of Naxos island (Greece), Quat. Int., 266, 81-93.

Evelpidou, N., D. Melini, P. A. Pirazzoli and A. Vassilopoulos (2014). Evidence of repeated late Holocene rapid subsidence in the SE Cyclades (Greece) deduced from submerged notches, Int. J. Earth Sci., 103 (1), 381-395.

Evelpidou, N., E. Tziligkaki and A. Karkani (2018). Submerged Antiquities on Paros and Naxos Islands, Aegean Sea, Greece: New evidence for the Mean sea level during the late Bronze age and the Roman period, Bull. Geol. Soc. Greece, 52, 71- 97.

Fotiou, F. K. (1973). Archaeological Survey on Paros Island. Archaeologiki Ephimeris, Chronika (1973), 1-14.

Furlani, S. (2012). The Geoswim Project: snorkel-surveying along 250 kilometres of the Southern and Western Istrian coast, Alp. and Mediterr. Quat., 25 (2), 7-9.

Galili, E. and J. Sharvit (1998). Ancient coastal installations and the tectonic stability of the Israeli coast in historical times, in Coastal Tectonics I. S. Stewart and C. Vita-Finzi (Editors), Geol. Soc. Lond. Spec. Publ., 146, 147-163.

Galili, E., D. Zviely and M. Weinstein-Evron (2005). Holocene sea-level changes and landscape evolution on the northern Carmel coast (Israel), Mediterranee, 1 (2), 1-8.

Gautier, P., J. -P. Brun and L. Jolivet (1993). Structure and kinematics of Upper Cenozoic extensional detachment on Naxos and Paros (Cyclades Islands, Greece), Tectonics, 12, 1180-1194, doi:10 .1029/93TC01131.

Graves, Th. (1842). Map of Paros and Naxos, H.M.S. Beacon 1842, Publ. London Hydrographic Office, 1847.

Higgins, C.G. (1980). Nips, Notches, and Solution of Coastal Limestone: an overview of the problem with examples from Greece, Estuar. Coast. Marine Sci., 10, 15-30.

Hopley, D. (1986). Beachrock as a sea-level indicator, in Sea-level research: a manual for the collection and evaluation of data O. Van de Plassche (Editor), Galliard Printers, Great Yarmouth, UK, 157-173.

Jackson, J. and D. McKenzie (1984). Rotational mechanisms of active deformation in Greece and Iran, in The geological evolution of eastern Mediterranean J. E. Dixon and A. H. F. Robertson (Editors), Geol. Soc. Lond. Spec. Publ., 17, 743-754.

Jevrejeva, S., J. C. Moore, A. Grinsted, A. P. Matthews and G. Spada (2014). Trends and acceleration in global and regional sea levels since 1807, Glob. Planet. Change, 113, 11-22, doi:10.1016/j.gloplacha.2013.12.004.

Kahle, H.-G., C. Straub, R. Reilinger, S. McClusky, R. King, K. Hurst, G. Veis, K. Kastens and P. Cross (1998). The strain rate field in the eastern Mediterranean region, estimated by repeated GPS measurements, Tectonophysics, 294, 237- 252.

Kapsimalis, V., K. Pavlopoulos, I. Panagiotopoulos, P. Drakopoulou, D. Vandarakis, D. Sakelariou and C. Anagnostou (2009). Geoarchaeologi-cal challenges in the cyclades continental shelf (Aegean Sea), Z. Geomorphol., 53, suppl. 1, 169-190.

Karali, L. and F. Mavrides (1998). The first appearance of the vine. Concerns and suggestions for the integration of the vine and its products in the Neolithic and Early Bronze Age of northern Greece, Proceedings of the $5^{\text {th }}$ Workshop Vine-Wine History in the Wine History in the Region of Macedonia and Thrace, Naoussa 1719/9/1993, ETVA, Athens, 150-157.

Karkani, A., N. Evelpidou, M. Vacchi, C. Morhange, S. Tsukamoto, M. Frechen and H. Maroukian (2017). Tracking shoreline evolution in central Cyclades (Greece) using beachrocks, Marine Geol., 388C, 25-37.

Karkani, A., N. Evelpidou, M. Giaime, N. Marriner, H. Maroukian and C. Morhange (2018). Late Holocene palaeogeographical evolution of Paroikia Bay (Paros Island, Greece), Comp. Rendus Geosci., 350 (5), 202-211.

Karkani, A., N. Evelpidou, M. Giaime, N. Marriner, C. Morhange and G. Spada (2019). Late Holocene sea-level evolution of Paros island (Cyclades, Greece), Quat. Int., 500, 139-146.

Kelletat, H. (1997). Mediterranean coastal biogeomorphology: processes, forms and sea-level indicators, in Transformations and evolution of the Mediterranean coastline F. Briand and A. Maldonado (Editors), Bulletin de l’Institut Océanographique Monaco, CIESM Science Series n³, no sp. 18, 209-226.

Kelletat, H. (2005). Notches, in Encyclopedia of Coastal Science: Encyclopedia of Earth Sciences Series M. L. Schwartz (Editor), Springer, Dordrecht, 728-729. 


\section{Eleni Kolaiti and Nikos Mourtzas}

Kolaiti, E. (2019). Changes in the anthropogenic environment along the eastern coast of the Peloponnese on the basis of archaeological and morphological indicators of the Late Holocene relative sea level changes. Proposing a geoarchaeological method of approach, $\mathrm{PhD}$ Thesis, University of the Peloponnese, available at: National Documentation Centre of Greece, National Archive of $\mathrm{PhD}$ Theses, https://www.didaktorika.gr/eadd/handle/10442/44943.

Kourayos, Y. (2015). Paros-Antiparos-Despotiko: From prehistoric to contemporary times, Edition Municipality of Paros Island, Tourism and Development Committee.

Kraounaki, I. (2012). Coastal archaeological and geological investigations on Paros-Antiparos-Despotiko islands in 2001, Archaeologikon Deltion, 56-59 (2001-2004), B (6): Chronika, 558-568.

Kreemer, C. and N. Chamot-Rooke (2004). Contemporary kinematics of the southern Aegean and the Mediterranean Ridge, Geophys. J. Int., 157 (3), 1377-1392.

Kythnos Excavation Project 1990 - 2014. Annual Excavation reports 2005-2011, http://extras.ha.uth.gr/kythnos/index.php?page=home.

Lambeck, K. (1995). Late-Pleistocene and Holocene sea-level change in Greece and southwestern Turkey: a separation of eustatic, isostatic and tectonic contributions, Geophys. J. Int., 722, 7022-7044.

Lambeck, K. (1996). Sea-level changes and shoreline evolution in Aegean Greece since Upper Paleolithic time, Antiquity, 70, 588-611.

Lambeck, K., M. Anzidei, F. Antonioli, A. Benini and A. Esposito (2004). Sea level in Roman time in the Central Mediterranean and implications for recent change, Earth Planet. Sci. Lett., 224, 563-575.

Lambeck, K. (2014). Of moon and land, ice and strand: sea level during glacial cycles, The Annual Balzan Lecture2012, 5, L.S. Olschki.

Lambeck, K. and A. Purcell (2005). Sea-level change in the Mediterranean Sea since the LGM: model predictions for tectonically stable areas, Quat. Sci. Rev., 24, 1969-1988.

Lambeck, K., F. Antonioli, M. Anzidei, L. Ferranti, G. Leoni, G. Scicchitano and S. Silenzi (2011). Sea level change along the Italian coast during the Holocene and projections for the future, Quat. Int., 232, 1-2, 250-257.

Le Pichon, X., N. Chamot-Rooke and S. Lallemant (1995). Geodetic determination of the kinematics of central Greece with respect to Europe: implications for eastern Mediterranean tectonics, J. Geophys. Res., 100, 12675-12690.

Lilimpaki-Akamati, M. (1998). Viticulture and evidence on the worship of Dionysus in Pella, Proceedings of the 5th Workshop on the Vine-Wine History in the Wine History in the Region of Macedonia and Thrace (Naoussa, 1719/9/1993), ETVA, Athens, 60-67.

Lykousis, V. (2009). Sea-level changes and shelf break prograding sequences during the last 400 ka in the Aegean margins: subsidence rates and palaeogeographic implications, Cont. Shelf Res., 29 (16), 2037-2044.

Malandri, C., K. Soukis, M. Maffione, M. Özkaptan, E. Vassilakis, S. Lozios and D. J. J. van Hinsbergen (2016). Verticalaxis rotations accommodated along the Mid-Cycladic lineament on Paros Island in the extensional heart of the Aegean orocline (Greece), Lithosphere, 9 (1), 78-99, GSA Data Repository Item 2016359, doi:10.1130/L575.1.

Mauz, B., M. Vacchi, A. Green, G. Hoffmann and A. Cooper (2015). Beachrock: a tool for reconstructing relative sea level in the far-field, Marine Geol., 362, 1-16.

Mendoni, L.G. and N. D. Mourtzas (1990). An archaeological approach to coastal sites: the example of the ancient harbor of Karthaia, Proceedings of Triemero Aigaiou, 21-23 December 1989, Philologikos Syllogos "Parnassos" (Athens, Greece), Parnassos Journal, v. AB', 387-403.

Morrison, A.I. (1968). Relative Sea-Level Change in the Saliagos area since Neolithic Times - Appendix I, in Excavations at Saliagos near Antiparos D. J. Evans and C. Renfrew C. (Editors), The British School of Archaeology of Athens, Thames and Hudson, 92-98.

Mourtzas, N. (2007). Ancient harbour installations on the coast of Palaeopolis, in Palaeopoli of Andros: twenty years of archaeological research Lydia Palaiokrassa-Kopitsa (Editor), 104-108.

Mourtzas, N.D. (2010). Sea level changes along the coasts of Kea island and palaeogeographical coastal reconstruction of archaeological sites, Bull. Geol. Soc. Greece, 43 (1), 453-463.

Mourtzas, N.D. (2012). A palaeogeographic reconstruction of the seafront of the ancient city of Delos in relation to Upper Holocene sea level changes in the central Cyclades, Quat. Int., 250, 3-18.

Mourtzas, N. (2018). Palaeogeographic reconstruction of the coast of ancient Andros, in Palaiopolis, Andros: thirty years of excavation research Lydia Palaiokrassa-Kopitsa (Editor), Kaireıos Library, Andros, 56-66. 
Mourtzas, N.D. and E. Kolaiti (1998). Interaction of geological and archaeological factors: evolvement of the prohestoric and historical settlements and constructions in relation to the sea level changes on the Coast of Keos Island, in Kea - Kythnos: history and archaeology, L. G. Mendoni and A. Mazarakis Ainian (Editors), Proc. Intern. Symp. Kea-Kythnos, $22-25$ June 1994, Meletimata, 27, 679-693.

Mourtzas N.D. and E. Kolaiti (2016). Holocene sea level changes and palaeogeographic reconstruction of the Ayia Irini prehistoric settlement (Keos Island, Cyclades archipelago, Greece), in Géoarchéologie des îles de Méditerranée/Geoarchaeology of the Mediterranean Islands M. Ghilardi (Editor), CNRS Éditions, Paris, 119-135.

Nikolantonakis, K. and V. Amoiridou (2011). Ancient Greek Technology (I): Viticulture and Wine Making, http://www.tmth.gr/sciencerelated/64-arxaia-elliniki-technology/404-ampelourgia-kai-paraskevi-oinou.

Okal, E.A., C. E. Synolakis, B. Uslu, N. Kalligeris and E. Voukouvalas (2009). The 1956 earthquake and tsunami in Amorgos, Greece, Geophysical Journal International, 178 (3), 1533-1554.

Papadopoulos, G.A. and S. B. Pavlides (1992). The large 1956 earthquake in the South Aegean: macroseismic field configuration, faulting and neotectonics of Amorgos island, Earth Planet. Sci. Lett., 113, 383-396.

Papanikolaou, D. (1977). On the structural geology and tectonics of Paros Island (Aegean Sea), Annales Géologiques des Pays Helléniques, 28, 450-463.

Papanikolaou, D. (1980). Contribution of the geology of the Aegean Sea, Annales Géologiques des Pays Helléniques, 30, 65-93.

Papanikolaou, D., V. Sabot and T. Papadopoulos (1981). Morphotectonics and Seismicity in the Cyclades, Aegean Sea, Zeits. Geomorphol., N.F. Suppl. Bd., 40, 165-174.

Papathanassopoulos, G. and D. Schilardi (1981). An underwater survey of Paros, Greece, 1979: Preliminary report, International Journal of Nautical Archaeology, 10 (2), 133-144.

Papazachos, B.C., V. G. Karakostas, C. B. Papazachos and E. M. Scordilis (2000). The geometry of the Wadati-Benioff zone and lithospheric kinematics in the Hellenic arc, Tectonophysics, 319, 275-300.

Pavlopoulos, K., V. Kapsimalis, K. Theodorakopoulou and I. P. Panagiotopoulos (2011). Vertical displacement trends in the Aegean coastal zone (NE Mediterranean) during the Holocene assessed by geo-archaeological data, The Holocene, 22 (6), 717-728.

Peltier, W.R. (2004). Global glacial isostasy and the surface of the ice-age Earth: the ICE-5G (VM2) model and GRACE, Annu. Rev. Earth Planet. Sci., 32, 111-149.

Peltier, W.R., D. F. Argus and R. Drummond (2015). Space geodesy constrains ice ageterminal deglaciation: the global ICE-6G_C (VM5a) model, J. Geophys. Res. Solid Earth, 120 (1), 450-487.

Pirazzoli, P.A. (1986). Marine notches. In: Van de Plassche, O. (Ed.), Seal-level Research: A Manual for the Collection and Interpretation of Data, Geo Books, Norwich, 361-400.

Plomaritis, T. (1999). Morphology and Geochemistry of the Beachrocks of Sifnos (Greece), MSc Thesis, University of Southampton.

Porat, N., D. Sivan and D. Zviely (2008). Late Holocene embayment and sedimentological infill processes in Haifa Bay, SE Mediterranean, Israel J. Earth Sci., 57, 21-23.

Poulos, S.E., G. Ghionis and H. Maroukian (2008). Sea-level rise trends in the Attico-Cycladic region (Aegean Sea) during the last 5000 years, Geomorphology, 107 (1-2), 10-17.

Robert, E. (1982). Contribution à l'Étude Géologique des Cyclades Grèce: l'Ile de Paros, These 3eme cycle: Orsay, France, Universite de Paris-Sud (Orsay).

Roy, K. and W. R. Peltier (2018). Relative sea level in the Western Mediterranean basin: A regional test of the ICE7G_NA (VM7) model and a constraint on late Holocene Antarctic deglaciation, Quat. Sci. Rev., 183, 76-87.

Roux, J. (1804). Recueil des principaux plans, des ports, et rades de la Méditerranée dont 40 ont été derniérement publiés par Jean Joseph Allezard ancien Capitaine de Marine et plusieurs des autres corrigés, chez Yves Gravier Libraire sous la Loge de Banchi, Port Paros sur l'isle de ce nom, http://eng.travelogues.gr/collection.php?view=188.

Rubensohn, O. (1901). Paros II : Topographie, Athenische Mitteilungen, 26, 157-222.

Rubensohn, O. (1949). s. Paros, Paulys Real-Encyclopädie der Classischen Altertumswissenschaft, Neue Bearbeitung, 18 (4), 1781-1872.

Scarlatidou, K.E. (2004). Ancient vineyard in Thermi (Sedes) Thessaloniki, Proceedings of the Symposium Oinon Istoro III: T' ampelanthismata (Ktima Gerovasileiou, Epanomi Thessalonikis, 15/4/2004), Athens, 27-36.

Schilardi, D. (1973). A Fortified Acropolis on the Oikonomos Island of Paros, Archaeologika Chronika, 6, 260-265.

Scicchitano, G., C. R. Spampinato, F. Antonioli, M. Anzidei, V. Lo Presti and C. Monaco (2018). Comparing ancient 


\section{Eleni Kolaiti and Nikos Mourtzas}

quarries in stable and slowly uplifting coastal area located in eastern Sicily, Italy, Geogr. Fis. e Din. Quat., 41, 81-92.

Stanford, J.D., R. Hemingway, E. J. Rohling, P. G. Challenorb, M. Medina-Elizaldea and A. J. Lesterc (2011). Sea-level probability for the last deglaciation: a statistical analysis of far-field records, Glob. Planet. Change, 79, 193-203.

Stocchi, P., N. Evelpidou, A. Vassilopoulos, P. Pirazzoli, G. Spada and G. Ruggieri (2010). Sea-level change model predictions based on geomorphological data in Cyclades (Greece) and Tunisia, EGU General Assembly 2010 (Vienna, Austria, 2-7/5/2010), 13057.

Strasser, A., E. Davaud and Y. Jedoui (1989). Carbonate cements in Holocene beachrock: example from Bahiret el Biban, southeastern Tunisia, Sediment. Geol., 62, 89-100.

Taymaz, T., J. A. Jackson and D. McKenzie (1991). Active tectonics of the North and Central Aegean Sea, Geophys. J. Int., 106, 433-490.

Trenhaile, A.S. (2015). Coastal notches: Their morphology, formation, and function, Earth-Sci. Rev., 150, 285-304.

Turner, J.R. (2005). Beachrock, in Encyclopedia of Coastal Science M. L. Schwartz (Editor), Kluwer Academic Publishers, The Netherlands, 183-186.

Zafeiropoulos, N. (1960). Antiquities and monuments of Aegean islands, Archaeologikon Deltion, 16, A, 235.

Zafeiropoulou, F. (1998). Paros: Archaeological Guide, Publ. Archaeological Receipts and Expropriations Fund, Hellenic Ministry of Culture and Sports, Athens.

Vacchi, M. (2012). Coastal geomorphology of lesvos island: processes, Late Quaternary evolution and the neotectonic implications, PhD Thesis, Universita degli Studi di Genova.

Vionis, A.K. (2006). The Thirteenth-Sixteenth-century Kastro of Kephalos: A Contribution to the Archaeological Study of Medieval Paros and the Cyclades, The Annual of the British School at Athens, 101, 459-492.

Vordos, A. (2005). Timeless methods of vineyard planting: The case of Megara, Proceedings of the 2nd Congress on the Ancient Greek Technology (TEE, EMAET, KDEMT), 17-21 October 2005, 380-387.

Vousdoukas, M., A. Velegrakis and T. A. Plomaritis (2007). Beachrock occurrence, characteristics, formation mechanisms and impacts, Earth-Sci. Rev., 85, 23-46. 